\title{
Energy Business Transformation \& Earth System Resilience: a metabolic approach
}

\author{
Martin E. Wainstein ${ }^{1 *}$, Jerôme Dangerman², Stephanie Dangerman ${ }^{3,4}$ \\ ${ }^{1}$ Australian-German Climate \& Energy College, University of Melbourne, Australia \\ ${ }^{2}$ Potsdam Institute for Climate Impact Research, Potsdam, Germany \\ ${ }^{3}$ Radboud University, Nijmegen, Netherlands. ${ }^{4}$ Saxion University of Applied Sciences, Netherlands. \\ ${ }^{*}$ Corresponding author: martin.wainstein@climate-energy-college.org
}

\begin{abstract}
At present, an energy transition consistent with achieving the goals set out by the Paris climate agreement is not occurring, primarily due to lock-in dynamics at the societal and energy business complex level. To contribute to discussions on how to unlock a major system transformation, we introduce here a new framework that characterises the energy business as a system and traces its metabolism. Drawing analogies with biology and using metabolic maps, we present a systems analysis across-scales; from the Earth system down to the energy business purpose level. Our analysis shows energy directors and managers face unfavourable conditions that inhibit radical business model decisions consistent with safely achieving emission targets. One such condition is how the intensity of the Earth system feedback signal is significantly reduced by the time it arrives at the corporate decision-making level, primarily due to social information filters and corporate law. Secondly, the shareholder profit maximization purpose of companies is found to hold a systemic role in the energy business lock-in and may be incompatible with avoiding dangerous climate change. To achieve an energy transformation that safeguards Earth system resilience, our discussion suggests focusing on the intrinsic purpose and governance of the system, arguing that relying on external economic adjustments alone, such as carbon pricing, may help but could fall short of achieving the necessary shift. Fundamental Earth stewardship is needed from energy business actors. Like with nationally determined contributions (i.e. INDCs), a bottom-up approach to proposing contributions to climate-consistent business model pathways may facilitate the dialogue.
\end{abstract}

Keywords: Earth system; climate change; energy transition; complex adaptive systems; energy business; corporate governance.

\section{Introduction}

Solutions to prevent further damage of the Earth system due to anthropogenic climate change have now very little room for failure. To stay below a $1.5^{\circ} \mathrm{C}-2^{\circ} \mathrm{C}$ warming guardrail, global carbon emissions must peak within the next three years and follow a steady decline towards a zero emission state by mid-century (Figueres et al., 2017; Rockström et al., 2016). The required transformation of the energy system is of unprecedented scale and speed (Rogelj et al., 2015), and implies a radical shift of the established fossil fuel business model.

It is well understood that transitioning the whole energy system to meet climate targets can represent a significant devaluation of existing fossil fuel assets (IPCC, 2014). From the perspective of firmly established corporations in what we characterise as the energy business system $\left(\mathrm{EBS}^{1}\right)$, this translates to an unprofitable endeavour with remarkable managerial challenges. If maximising profits is a fundamental purpose of business systems, then do large fossil-based firms have the legal, political, economic and cultural capability to make the radical business model decisions required to protect Earth system stability? If market-based policies such as carbon pricing fail to produce profitability tipping points that wholly shift investment schemes from fossil to nonfossil in the required timeframe, is humanity to expect a self-imposed creative destruction of the EBS? We explore these crucial questions in this paper and provide answers considering a holistic perspective.

Analysing business systems involves considering the societal institutions and interdependent agents such as the state, labour and financial markets, as well as the dominant cultural beliefs and norms on trust, property, law and ethics (Whitley, 1999). An even more comprehensive framework of business systems can include a lens of complexity science; understanding that business actors and the aggregate social, technological and ecological elements add to more than the sum of the parts, exhibit non-linear dynamics, constant change and adaptation. Business systems, however, have been significantly underrepresented in science and policy discussions on how to achieve global climate targets. More importantly, the global business of hydrocarbon-based energy lacks

\footnotetext{
${ }^{1}$ We introduce here the abbreviation EBS for the energy business system, defined in page 5 as "the set of actors, processes, networks, established practices, mindsets and norms involved in the business of delivering this energy to society." Other non-standard abbreviations used throughout this article include CAS, for complex adaptive Systems; IOC, for investor owned company; and NOC, for nationally owned company.
} 
frameworks to discuss their role in maintaining Earth system resilience (Bjørn et al., 2017; Paul et al., 2017). In light of this gap, this paper has two main goals. The primary one is to introduce a holistic framework for the relationship between the EBS and the Earth system. For this, we use a conceptual meta-diagram or map to illustrate the most relevant elements and dynamics, scoping and characterising the EBS in terms of its metabolism. This 'EBS metabolism' framework uses a systems thinking approach and seeks to contribute to a growing literature and exploration in the intersection of business and transition theory. This intersection studies the role that business models have in both affecting and being affected by wider societal, technological and ecological systemic shifts, or sociotechnical and socioecological transitions for short (Bidmon and Knab, 2018; Gruner and Power, 2017; Williams et al., 2017).

A second goal of the paper, is to use this conceptual framework to discuss fundamental business changes needed to ensure long term climate stability. We specifically focus on profit maximisation and limited liability from a shareholder and manager perspective; aspects that have been previously discussed in broad business and managerial ethics literature, such as in Stout and Blair's (2017) distinction of the dynamics in shareholder versus stakeholder wealth maximisation, or in recent articles like Bower and Paine (2017), which question the accountability of shareholders under limited liability. In fact, the direct relationship between shareholder primacy and higher carbon emissions was recently explored and shown by Kock and Min $(2016)^{2}$, who also argue that large international climate agreements are already influencing shifts in core tenets of corporate law and business systems. Even more specific to the EBS, Benjamin (2016) analyses how shareholder wealth maximisation inhibits emission curbing efforts of large energy corporations, exposing key tensions between proactive climate action and fundamentals in the current corporate legal culture. We expect these core sustainability questions of the EBS will be more pressing as the window to achieve climate targets narrows.

Structurally, this paper builds a framework by presenting an analysis tracing key feedback dynamics among and across systems-from the Earth system to the EBS. In other words, we look at the group of nested systemssystems inside larger systems. To visualize nested systems, think, for example, in a single human cell inside a tissue, inside an organ, inside the human body, all which have respective degrees of complexity. This approach might help us understand properties that confer stability and adaptation at different scales, and identify leverage points to enable transformation (Meadows and Wright, 2008). In fact, considering both biology and business are characterised by complex adaptive systems, biology has much to inform business on how to achieve global stability, as presented by Reeves and Levin (Reeves and Levin, 2017). More specifically, our framework draws particular analogies with the processes of reinforcing and negative feedbacks by which biological metabolisms have positively affected life-supporting conditions in the Earth system. Furthermore, as a key advance in our analysis, we consider the systemic role of business purpose in corporate governance to sustain or shift what we frame as the current metabolism of the EBS. Discussing purpose as a governing element in business systems contributes to business model transition theory, which historically focuses on using models to explain how companies make money under different contexts, but rarely include shifts on why they make money in the first place (Loorbach and Wijsman, 2013; Wainstein and Bumpus, 2016).

Section 2 lays down the larger and historical Earth system context of climate change and the energy system, introducing metabolisms as a key framework. This is followed by a revision and discussion of lock-in studies in the EBS. Section 4 presents the original framework of the EBS metabolism and accompanying map, and the core analysis of relevant EBS feedback dynamics. Section 5 provides concluding remarks with suggestions to policymakers and business actors.

\section{Background \& metabolic approach}

This section aims to introduce and review the broader concepts that are integrated in our metabolic approach. Since the paper's approach looks at the relationship between the energy business and Earth from the lens of nested complex systems, this section starts by introducing why and how we include such a broad system like Earth into the equation. We follow this by laying down the metabolic frame to industrial energy dynamics across system scales. Finally, an important background to introduce for the paper relates to theories of complex systems and its application to business and the energy transition. However, because of the interdisciplinary nature of this endeavour, we cannot cover a detailed review of it in this section. We have thus defined here the main terms and added more extensive descriptions in the Supplementary Material.

\footnotetext{
2 Kock and Min (2016) also provide a valuable background work when evaluating corporate law and environmental governance. They review the 'origins of law,' with clear distinctions between countries with an Anglo-Saxon case-based 'common law' -associated with a higher focus on shareholder primacy- versus countries that apply a code-based 'civil law.'
} 


\subsection{Earth's metabolic singularities and their nested complex systems}

Stable life-supporting conditions in the Earth system slowly evolved thanks to biologic, atmospheric and geologic dynamics (Lovelock and Watson, 1982). Photosynthesis, the metabolism that evolved around 3 billion years ago, responsible for all atmospheric oxygen and most biochemical fixation of $\mathrm{CO}_{2}$, played a fundamental role in this process (Lyons et al., 2014)(see Fig. 1a). Utilizing the solar energy captured by photosynthesis, hydrocarbon combustion evolved in the human energy system as an exogenous metabolism -i.e. occurring outside the human body, as opposed to respiration - to power tools and provide fundamental services. But by re-introducing the sequestered $\mathrm{CO}_{2}$ into the atmosphere, fossil fuel combustion has been the major contributor to the disruption of the long-held Earth system balance. These two metabolisms have common properties to highlight. Understanding the dynamics in their large-scale processes can provide insights on how to preserve this balance.

While metabolisms are a set of life-sustaining chemical transformations occurring in the cells of living organisms, the term has been extended to describe the collection of processes involving material transformations and energy flow in complex systems such as cities, industries, or the overall material flow in human activities (i.e. anthropogenic metabolism)(Ayres, 1989; Fischer-Kowalski and Weisz, 1999). In its broader sense, metabolisms are useful to trace relationships and interdependencies of nested systems and their effects at different scales (de Molina Navarro and Toledo, 2014). For example, in biological systems the metabolism occurs in each specific cell - eg. in a leaf- but produces orchestrated effects in a multi-cellular organism, on the overall population, and on interactions of an entire community - eg. in a forest.

Metabolic dynamics in nested systems are relevant to understand how processes driven by living systems escalate, thanks to feedback loops, into chemical changes on the whole Earth ecosystem (Lenton and van Oijen, 2002). Particularly, here we refer to a "metabolic singularity" when the emergence of a specific metabolism exponentially and irreversibly changes the course of a planet's physical and chemical properties-affecting its biocapacity and leaving a distinguishable trace in the geologic record.

In terms of increasing life-supporting conditions, the most important metabolic singularity on Earth is, as introduced, the evolution of photosynthesis. The rise of atmospheric oxygen coupled with sequestration of $\mathrm{CO}_{2}$ affected the whole planet due to positive feedback loops (Lyons et al., 2014; Shih, 2015). This means the effects of life on the Earth system produce conditions for even higher metabolic rates (Lovelock and Lovelock, 2000). A classic example is how $\mathrm{O}_{2}$ facilitated the formation of an ozone layer, blocking UV radiation, and allowing more life to emerge. Additionally, in at least two main oxidation stages, the present concentration of $21 \%$ atmospheric $\mathrm{O}_{2}$ was achieved and stabilized by negative feedbacks, which slow down the activity, as well as positive feedback loops that directly counteract with it. Examples of these regulatory mechanisms include fires, methanogenesis and large biogeochemical effects (Lenton and Watson, 2000).

Like photosynthesis, anthropogenic hydrocarbon combustion is a metabolic singularity. Its impact on atmospheric chemistry unfolded with radical speed, causing an unnatural alteration of the climate system, and ushered in the Anthropocene as a new geologic epoch (Steffen et al., 2007). Its accelerated rate has been due to feedback loops, namely available energy for remarkable societal development and economic growth. However, unlike oxygenic photosynthesis, stabilizing feedbacks have not regulated the overall rate of combustion to a sustainable level, in spite of negatively affecting safe living conditions in the biosphere. From a systems point of view, the combustion metabolism in the energy system is characterised by being in a state of lock-in (Dangerman and Schellnhuber, 2013). Lock-in, as a term, is used considering different angles in the paper, from a pure mechanical process to a non-linear systemic condition. Next section describes these further. However, in simple words, it is the state of being stuck in a set of processes that reinforce themselves.

Figure 1 illustrates hydrocarbon combustion as a metabolic singularity in its historical context, and showing a state of lock-in from three perspectives. In doing so, the figure also summarises the set of quantitative data acting as general background of this work, and a specific quantitative reference for the stylized framework shown in figure 2. Figure 1a shows the Earth system's atmospheric record highlighting the $\mathrm{O}_{2}$ and $\mathrm{CO}_{2}$ concentration spikes produced by the photosynthesis and combustion metabolic singularities. Figure $1 \mathrm{~b}$ shows the historical $\mathrm{CO}_{2}$ emission trajectory from the energy system with the forecast under 'most likely' scenarios to 2035 showing trajectories to a well-over $2^{\circ} \mathrm{C}$ warming (BP, 2017; IEA, 2016a). Forecasts and scenarios can have biased assumptions, but still help inform whether present efforts to curb emissions are on track to meet a specific goal. In contrast to these forecasts, safe energy system emission pathways consistent with $1.5^{\circ} \mathrm{C}$ and $2^{\circ} \mathrm{C}$, require dropping emissions to zero by around 2050 and reaching negative emission levels by the end of the century. These safe emission caps are used to determine what is understood as the remaining atmospheric carbon budget (Rogelj 
et al., 2016). Figure 1c shows the energy system lock-in manifested in terms of fossil percentage of total primary energy-forecasted to remain around 80-85\% to 2035 (BP, 2016; De Stercke, 2014). Unless our present society can identify, engage and overcome the key sources sustaining lock-in of the energy system, humanity will have a slim chance of avoiding catastrophic changes in the climate system.

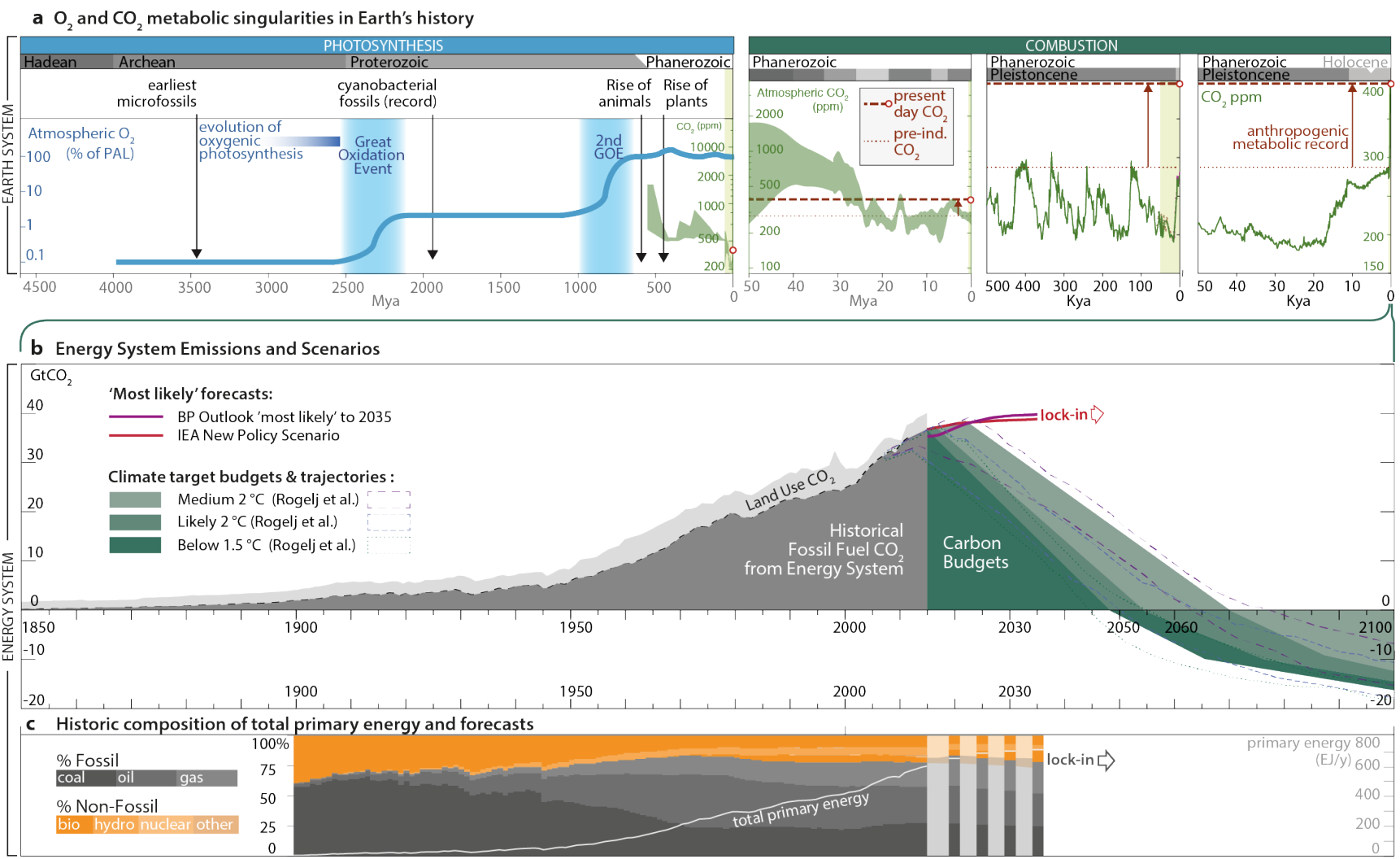

Fig 1 | Metabolic lock-in in the Earth and energy system. a) Evolution of present day levels of oxygen and $\mathrm{CO}_{2}$ in Earth's history, highlighting the role of living systems in specific metabolic events: photosynthesis and hydrocarbon combustion. Photosynthetic relevance on $\mathrm{O}_{2}$ levels (light blue) relative to present atmospheric levels (PAL), adapted from Shih (2015), Lenton (2016) and Lyons (2014). $\mathrm{CO}_{2}$ levels (green) and the geologic record of anthropogenic hydrocarbon combustion (red arrow) is shown through different timescales where yellow bands show the subsequent timeframe, based on (from left to right) (Jansen et al., 2007), (Masson-Delmotte, 2013), (Lüthi et al., 2008) and (Meinshausen et al., 2017). b) Energy system's $\mathrm{CO}_{2}$ emissions in the anthropocene and contrast between forecasted trajectories with $1.5^{\circ} \mathrm{C}$ and $2^{\circ} \mathrm{C}$ consistent scenarios and budgets. 'Most likely' emission show an emission lock-in trajectory (purple and red), based on IEA (2016c) and BP Outlook (Bidmon and Knab, 2018; 2017). $1.5^{\circ} \mathrm{C}$ and $2^{\circ} \mathrm{C}$ remaining budgets (green) are shown by area based on modelled scenarios from Rogelj et al. (2015) and showing the extent of required negative emissions by the end of the century. c) Fossil percentage of total primary energy consumption, adapted from De Sterck et al (2014; Gruner and Power, 2017) and forecasted trajectories that infer a fossil fuel lock-in at an energy infrastructure level (BP, 2017).

\subsection{A metabolic framework for combustion lock-in}

Emission trajectory and primary energy composition, as shown in Fig $1 \mathrm{~b} / \mathrm{c}$ are ways to illustrate how lock-in of the fossil fuel combustion metabolism manifests. However, a broader concept of lock-in in nature and social systems implies a systemic rigidity that reduces interaction with environmental signals to maintain internal conditions. A more advanced lock-in, or rigidity trap, represents the inability to respond to dangerous or even fatal threats from its environment (Carpenter and Brock, 2008; Scheffer and Westley, 2007). In economic terms, lock-in occurs when a technological standard remains in a market even though an alternative has significantly higher advantages (Arthur, 1989; David, 2001; Dosi, 1982). A more encompassing systems analysis of lock-in is therefore needed to understand its repercussions, identify and release its sources. Here, again, biology and human systems have valuable resemblance.

The dynamics involved in metabolic singularities - and the lock-in that facilitate them - can be studied in terms of the evolutionary behaviour of nested complex ${ }^{3}$ adaptive systems (CAS). The multiple social and

\footnotetext{
${ }^{3}$ Systems thinking (see for example: Meadows, 2008) is the main lens of analysis used in this paper to understand and characterize complexity in the EBS. Complexity is a core background theory to this work. A watch, for example, is a complicated system, it holds an intricate set of processes but still all linear in their
} 
technological elements of the energy system form a network with interactions at multiple system scales that can be considered a CAS (Bale et al., 2015; Smil, 2008). This means the system exhibits self-organizing traits, is in a constant process of adaptation and evolution with its environment, and its aggregate non-linear behaviour is not determined by a random association of factors nor the actions of its individual parts (Holland, 1992). In other words, not only is the CAS total more than the sum of its parts, it also changes by adapting to the environment thanks to dynamic feedback. More importantly, because of the strong feedback effects across scales, small local changes (eg. a new metabolism in a microscopic cell) can cascade and transform the entire system (i.e. the Earth's atmosphere) in a process called emergence. A similar reaction can occur when a CAS falls into a lock-in (Arthur et al., 1987): it becomes insensitive to environmental feedback and, in a rigidity trap, can bring about deleterious consequences replicating across systems.

The micro to macro effects in CAS follows from their nested hierarchical property, meaning they are often themselves composed of smaller CAS, and are in turn a component of a larger CAS (Holling, 2001). Energy business actors are nested in the broader energy system, which is nested in society, in turn a part of the Earth system. The business-energy-society-Earth link can be framed as a relationship between a human and a natural CAS, forming a large socioecological system. Large socioecological systems are characterized by stable states in space and time but can cross critical thresholds, which prevent the system from returning back to its previous stable state (Gunderson, 2000; Scheffer et al., 2009; Walker et al., 2004). Particularly, a persistent lock-in from a lower system scale can drive the whole socioecological system across a critical threshold. The Amazonian rainforest is a quintessential example of a large socio-ecological system approaching such a critical tipping point - with declining carbon sinks that may turn into sources - driven by reinforcing feedbacks and weak negative feedbacks in the human-nature CAS nexus (Brienen et al., 2015; Schellnhuber, 2009).

To prevent a local lock-in to have a macro effect on a socioecological system, the lower CAS needs to undergo a release of its resource, connectivity and resilience, transforming towards a new stable state (Gunderson, 2001). Release of resource and connectivity can manifest in different ways depending on the nature of the system. The essential transformation, however, is akin the process of creative destruction described by Schumpeter (2013) for business and the economy, and is part of what confers adaptability to a CAS - whether natural or human - in cycles of consolidation and reconfiguration (Holling and Gunderson, 2002). Transformation serves an adaptive function to the specific CAS that has fallen into extreme consolidation, but also to the overall system (Folke et al., 2010). For example, humans can fall sick from exposure to viruses but, in the process, strengthen the immunity system. In forests, small localized fires may seem destructive, but they help to both release nutrients and create higher robustness to the whole forest by preventing large-scale irreversible fires. In the energy business, an example of resource and connectivity release can include the forced division of Standard Oil, which allowed its resulting parts and new entrants to compete and drive innovation in the sector. Supplementary material SM1.1 further describes adaptive cycles of CAS in the context of large socioecological transitions, and figure SM1 represents how transformations or creative destructions in lower scales can confer higher resilience to it higher ones.

We apply the understanding of nested CAS to the framing of combustion in the energy system as a large-scale metabolic phenomenon. Figure 2 shows a stylized depiction of how the fossil fuel combustion can be placed as a metabolic singularity along the same linear chemical equation as the photosynthetic metabolism. They both represent dominant - and antagonistic - chemical transformations that affect physical properties of the Earth system's atmosphere. Both can be deconstructed into three major nested system levels according to different temporal and spatial scales. Lower and higher levels refer to the relative system's size. The business actor level is placed in the lower end of the combustion metabolism. Reinforcing, counteracting and negative feedbacks across these scales are represented with arrows of positive and negative signs. This multi-level representation allows a framework analysis borrowing from both a socioecological Panarchy (Gunderson, 2001) and sociotechnical transitions.

cause and effect, allowing its behavior to be predicted with exactitude. Biological organisms, on the other hand, can't be fully predicted in all processes since they hold non-linear reactions to different inputs. Complex systems appear also in social structures like economic markets. 


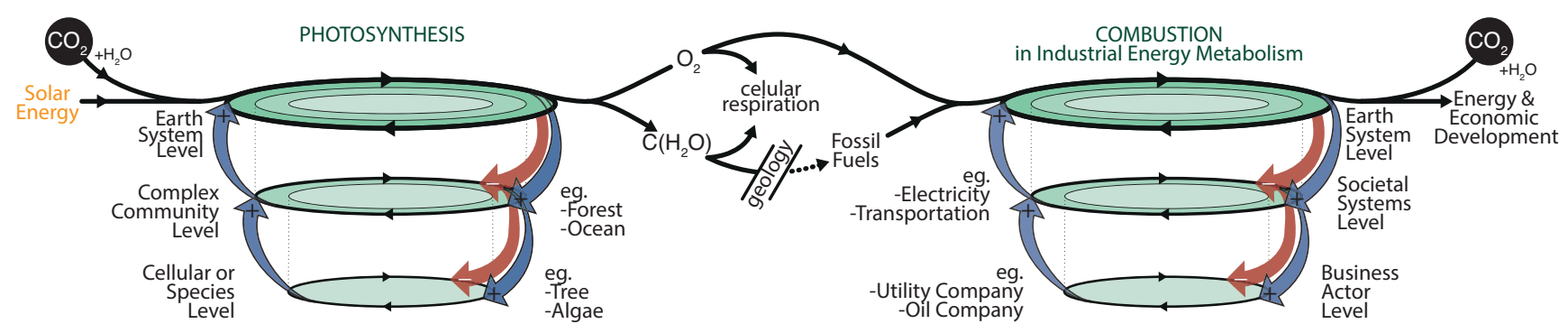

Fig. 2. Metabolic Singularities: Nested living complex systems with Earth system impact. Stylized conceptual illustration of combined natural -i.e. photosynthesis - and human - i.e. combustion - metabolisms that have a direct effect on life-supporting conditions at an Earth system level. The figure shows the nested property of how the basic relevant metabolic levels, characterised by complex adaptive systems, escalate to the global system level. Arrows with a positive and negative label represent positive and negative feedback loops across system scales. Anthropogenic combustion has been a metabolic singularity that affected lifesupporting conditions in under a century (see Fig 1a as a quantitative reference to this conceptual model).

Both social and technological, or sociotechnical for short, elements and dynamics are involved in the industrial energy complex shown in the right side of figure 1. Research on sociotechnical systems, particularly from a multiple (nested) level perspective, has now consolidated as a field to understand complex transitions to sustainability (Geels, 2002). We include and consider this line of research to our background framing of the energy system. Supplementary material SM1.1 particularly describes further the application of sociotechnical system research to energy system lock-in. Specifically, to provide further context of sociotechnical factors affecting the metabolic behaviour of the energy system, we consider an exercise on system dynamics adapted from Dangerman (2013). System dynamics is an area of research within systems thinking that applies concrete methods to portray and model the function of systems through positive feedback and negative feedback loops. Figure 3 shows a causalloop diagram explaining lock-in of the conventional energy system relative to the alternative one (non-fossil based), with both systems and Earth laid out in a multi-level perspective.

The severe lock-in, or rigidity trap of the energy system, contributes to the loss of resilience of the Earth system, the highest system in which it resides, driving it towards a transformation across stability thresholds. Positive feedback loops of the fossil-based energy system outcompete an alternative energy system that would counteract it, and negative feedbacks from a higher scale are not effective at shifting this process (see Fig 3b). One of the main properties giving rise to this disconnect, is that nested CAS are characterised by different relative speeds in the adaptive cycle of higher systems and lower ones (Dangerman and Schellnhuber, 2013). With longer temporal cycles, larger systems act as stabilising forces to lower systems (eg. law and policy influencing corporate/actor behaviour). Under a rigidity trap, the lower system constantly outpaces the higher system, and builds resilience to its feedback. This cross-scale rhythm mismatch builds tensions that can drive a system towards collapse.

To dive deeper into sources of lock-in and identify leverage points that can bring about transformation in the right system scale, we focus on the EBS as a critical sublevel within the global context. 


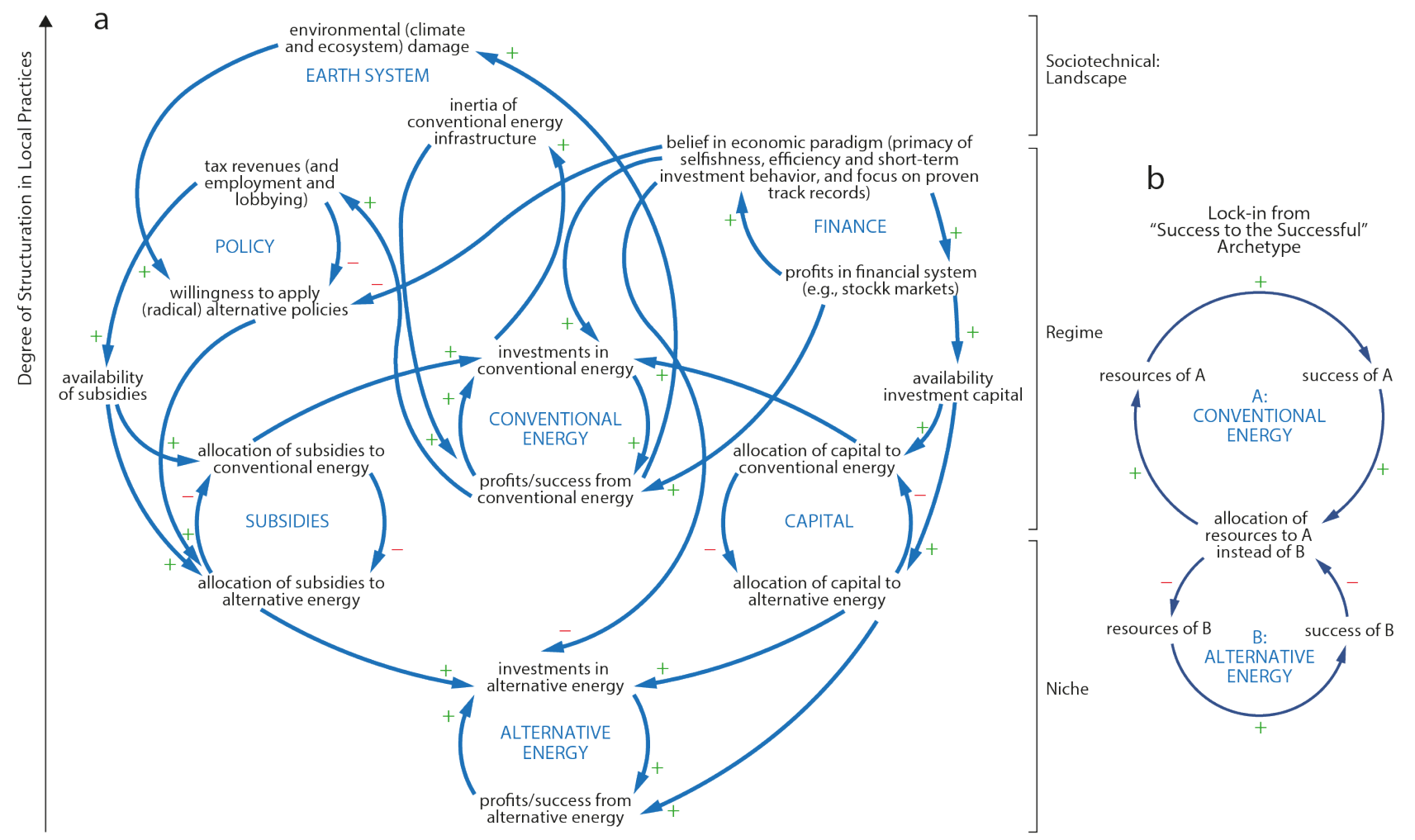

Figure 3 | System dynamics in conventional energy lock-in. Causal loop diagram (CLD) from a 'multi-level perspective' (MLP) on sociotechnical systems and 'Success to the Successful' archetype. a) Critical systems that affect the competitive performance of the conventional vs. the alternative energy system are depicted in a CLD of system dynamic modeling, where (+) signs represent a positive feedback and (-) represent a negative one. This simplified CLD is adapted from Dangerman (2013) by organizing the systems along the $y$-axis of 'increasing structuration in local practice' used in the MLP of sociotechnical system theory (Geels and Kemp, 2006), which produces a distinction between a sociotechnical landscape (i.e. most structured and hardest to change), a regime (i.e. a stable state of societal and technological elements giving perpetuity to technological trajectory) and a niche (i.e. protected pockets where experimentation and innovation occurs). b) 'Success to the Successful' archetype by which the conventional outcompetes and locksout its alternative energy system (Dangerman and Schellnhuber, 2013), placed in a MLP arrangement.

\section{Framing the energy business system}

This section defines and characterises the EBS in the climate challenge context. This exercise is a central component for the next section, the main output of the paper which will integrate the framing of section 2 and 3 into a consolidated conceptual framework of the EBS metabolism and its map.

\subsection{The global system for energy supply}

Whilst the global energy system includes the whole set of conversions from primary, secondary, final energy to ultimately energy services for end users, the EBS can be understood as the set of actors, processes, networks, established practices, mindsets and norms involved in the business of delivering this energy to society. Figure $4 \mathrm{~d}$ shows a diagram of the global energy supply chain, with the EBS spaning from upstream to retail.

The EBS essentially represents the energy supply sector. Supply forms an interdependent network with the end-use sector (i.e. industry, transport, buildings, agriculture) sharing cultural, business and consumption practices. Considering sources of emission lock-in we place specific emphasis on the supply side ${ }^{4}$ for several reasons. The EBS and its actors are: owners of assets with a higher infrastructural inertia and longer-lived capital stock relative to demand (Riahi et al., 2012); direct facilitators and administrators of fossil fuels in the global energy economy -through exploration, extraction, refining and distribution; responsible for both the largest historic emission profile by sector and highest emission increase in the last 16 years (Bruckner T., 2014); and channel well over three times the amount of energy-related investment than demand side components (IEA, 2016b) - a ratio expected to further increase by 2035 (IEA, 2014).

\footnotetext{
${ }^{4}$ To clarify, we don't find end-use sector dynamics negligible in terms of lock-in, we acknowledge their role in producing inertia in the supply chain (Rocco et al., 2018), but given the analysis presented, we consider the supply-sector more relevant for leverage points on system intervention.
} 
Moreover, the energy supply sector has a higher vested interest in the type and quantity of energy delivered than the end-use sector. In general, the end-use sector has remained agnostic to energy sources as long as they hold technological compatibilities to receive energy services. Finally, energy supply has been characterised by firms that have focused on scale and efficiency to maximise economies of scale, leading to the world's largest companies that behave as highly complex self-renewing systems with central administrative structures; all factors that make them particularly susceptible to lock-in (Maula, 1999; Reeves and Deimler, 2011).

\subsection{Big business lock-in in the energy supply chain}

Recent carbon accounting efforts have allowed to trace present and historic energy emissions back to individual fossil fuel producers. Almost $60 \%$ of historic global energy emissions can be traced to production records of a set of 90 businesses $^{5}$ (Heede, 2014). These oil, gas and coal businesses, known also as 'carbon majors' (Starr, 2016), can be divided into three distinct groups: investor-owned companies (IOCs), nationally owned companies (NOCs) and nation states (see Fig. 4a). IOCs are the group of businesses with the most recognised global brands behind the energy business, which include examples such as Exxon, Chevron, Shell and British Petroleum. All major IOCs trade publicly in their respective stock exchanges. NOCs are incorporated businesses where over 50\% of shares are owned by a nation state. These include publicly traded examples such as Russia's Gazprom, as well as those that are closely held such as Saudi Aramco. Finally, a small group of Nation states directly run the business of supplying energy without using incorporated organisations. The most outstanding example of an emissionintensive Nation state business is China. Figure 4a shows the composition of carbon majors in terms of historical and recent traced emissions, organizational and legal classifications.

There are at least three features of EBS lock-in that are evident when analysing its largest business actors. First, carbon majors collectively hold $440 \mathrm{GtC}$ proven reserves (Heede and Oreskes, 2016; McGlade and Ekins, 2015). Their overarching business model, particularly those based on oil and gas, shows robust competitive and profitable forecasts as the 'bedrock' of the energy system (IEA, 2016c). This means that a business model lock-in adds inertia to a trajectory with potential to burn carbon quantities that would overshoot the current remaining $2^{\circ} \mathrm{C}$-consistent carbon budget of $275 \mathrm{GtC}$ by $60 \%$ (see Fig. 4c). In light of a $1.5^{\circ} \mathrm{C}$ transition timeframe, a shift from coal to gas as a transition fuel, or incorporating renewable subsidiaries with minor presence in portfolios is not considered here as a core business model shift. Second, maintaining the core business model sustains investment lock-in to further increase proven fossil fuel reserves. Global upstream capital spending-i.e. fossil fuel exploration and production - had a historic peak in 2014 of around U\$S700 billion/year (Barclays, 2013). Spending was reduced in subsequent years due to falling commodity prices but is expected to reach a resilient 6\% rebound in 2017 (OGJ, 2017). Third, both upstream and downstream assets of carbon major's supply chain, hold infrastructural lock-in. Existing sunk costs make a shift of the industrial landscape a highly unprofitable endeavour, and breaking-even these sunk cost assets commits future emissions - a concept more often termed as carbon lock-in, to which coal and liquified natural gas (LNG) assets are specifically susceptible (Christoph et al., 2015; Peter Erickson et al., 2015). An extension to infrastructure or technological lock-in can include the fact that the feasibility of a zeroemission or $100 \%$ renewable energy system with present technology is a contested topic (see Jacobson et al., 2017). Through either perception or real technological limitation of current renewables ${ }^{6}$, this allows fossil fuels (eg. gas) to be considered in the energy mix well passed 2050. An example of this is the role of gas in the 450 scenario of the IEA outlook (IEA, 2016c).

Business model, investment and infrastructure lock-in of the largest EBS actors alone directly contributes to the present inertia of emissions that can consume the Earth system carbon budget of $1.5^{\circ} \mathrm{C}-2^{\circ} \mathrm{C}$ warming before mid-century (IEA and IRENA, 2017; Rogelj et al., 2016). It is reasonable to expect that as global mean temperature rises, society's energy business dichotomy will be further intensified.

Multiple studies and business narratives have emerged to stress the business case for an integral transition to renewables (Risky Business, 2016), appealing to the standard business thinking and pointing to the growing extent of grid-parities that apply to new investments in several markets (Vishal Shah, 2015). Decarbonisation of the electricity system is well under way and examples from European countries showcase how policy can accelerate business conditions to mobilise a transition towards renewables. However, whilst in recent years there has been a notable investment change, it applies also primarily to the electricity sector and falls substantially short of a track

\footnotetext{
${ }^{5}$ Majors vs. non-majors are divided by a threshold of $>8$ million tonnes carbon per year ( $\mathrm{MtC} / \mathrm{yr}$ ) for fossil fuel production (Heede, 2014).

${ }^{6}$ A reasonable clarification is that the lock-in and EBS tensions that this paper highlights, could be significantly reduced in the case of the discovery or development of a disruptive zero-carbon and low-cost technology that requires little or no retrofit of current infrastructure (i.e. a hypothetical case).
} 
towards climate targets (Bumpus and Comello, 2017). Furthermore, even with the right signals, lock-in also represents the unfavourable systemic conditions to change incumbent's mindsets (Scheffer et al., 2003).

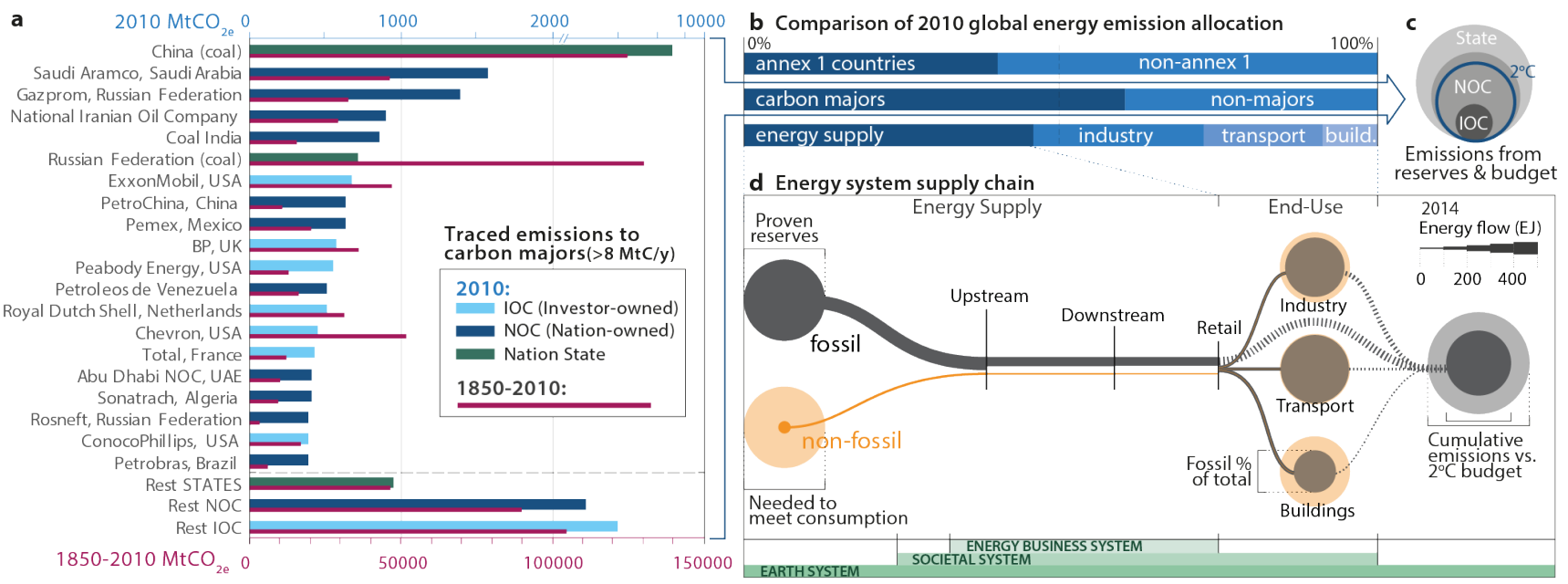

Figure 4 | Big Business in the energy supply chain. a) 2010 and historic emissions traced to a set of 90 carbon majors —energy businesses with productions over 8MtC/y (Heede, 2014). b) Comparison of 2010 emission allocations by country, business and sector groups. Carbon majors-traced emission account for over $60 \%$ of global levels, above those traced to the set of annex 1 countries, but whose sector's direct emissions represent 30\%. Adapted from Heede (2014), Heede and Oreskes (2016) and Gütschow et al. (2016). c) Carbon majors proven reserves available for market use exceed a $66 \%$ chance to a $2^{\circ} \mathrm{C}$ budget. d) Representation of the EBS scope in the global energy supply chain, shown using relative stocks (i.e. two variables presented relative to each other), sankey flows and atmospheric externalities. Simplified by fossil fuel and non-fossil sources. Constructed using data from (Bruckner T., 2014; De Stercke, 2014; GEA, 2012; IEA, 2016c).

\subsection{A rigidity trap in the energy business: the need for transformation}

The EBS, like its broader energy system, is in a rigidity trap (Dangerman, 2013). Whilst private actors have significantly mobilized in support of renewable energies, carbon major's business models still hold high resilience. As described in the previous section, high resilience prevents a release and reconfiguration in the adaptive cycle; a crucial process to avoid critical thresholds in the socioecological system (Carpenter and Brock, 2008). When firms face periods of uncertainty, they often focus on efficiency in their specialization. This, however, can directly strengthen the lock-in trap, since it removes diversity and redundancy and makes the system more prone to myopia of time by reducing the ability to foresee long term scenarios (Levinthal and March, 1993; Scheffer and Westley, 2007).

In the past, societal collapses have occurred due to an extended period of rigidity trap, involving a complex civilization with a severe resource mismanagement that fails to overcome a major threat due to its inability to mobilize both its physical and, particularly, its mental structures to new mindsets and worldviews (Diamond, 2006; Janssen et al., 2003). Additionally, actions and regulations that could have avoided them are significantly delayed when disproportionately powerful stakeholders benefit from the unregulated status quo (Scheffer et al., 2003). This is particularly the case of the EBS (Aghion et al., 2014; Geels, 2014; Oreskes and Conway, 2011).

Despite overwhelming scientific evidence of the Earth system approaching dangerous critical thresholds, and the agreements set in Paris, the rigidity trap preventing a radical and swift transformation of the energy system either appears to be too hard to escape, or forecasted to unlock itself only partially. The 2016 and 2015 British Petroleum (BP) Outlook to 2035 illustrates this scenario openly, calculating similar trajectories as the IEA New Policy Scenario and the IPCC baseline scenario (BP, 2017). Even with carbon prices rising to $\$ 60 / t$ and factoring in expected carbon regulations, the energy giant considers its business model will be safeguarded. Based on their 'most likely' projections, the industry's forecast will undergo changes in their energy mix, namely with a higher presence of natural gas, but still supply an increasing demand with over $80 \%$ fossil resources beyond 2035 (BP, 2016; ExxonMobil, 2017). These scenarios forecast a failure to meet the Paris agreement (Muttit, 2017).

So far, a mainstream stance of the major players of the fossil fuel industry is that, in order to meet climate targets, clear political regulations and a predictable internationally harmonized carbon price is needed (UNFCCC, 2015b). This is also the case suggested by classical economic theory (Goulder and Parry, 2008; Stern, 2007). Such interventions are highly valuable but, as we will argue, they may be insufficient to bring about a transformative 
outcome with the extent and speed required. Market-based regulations alone can reconfigure a mechanistic business system with low complexity, but today's large corporations, particularly those in the EBS, are complex and adaptive; they require a more holistic analysis for solution pathways (Reeves et al., 2017).

\subsection{Market based policies alone may not achieve EBS transformation}

Ongoing global mitigation efforts need to be evaluated for their effectiveness in intervening and releasing the EBS lock-in, transforming the world's largest industrial complex into one without contributions to loss of resilience in the Earth system. Additionally, given the direct relationship between the EBS and the Earth system, preventing dangerous lock-in from arising in the future calls for careful revisions in the system's properties.

Current policy options are varied (Somanathan et al., 2014). Direct legal regulations include environmental and technological standards that aim to improve end-use efficiency, which are considered enabling and complementary policies but not transformative (Croucher, 2011; Sorrell, 2007). The Paris agreement is an international legal framework but does not present any deliberate interventions for the energy system. At present, the most widespread evaluated interventions lie within the realm of market economics (Stern, 2007). The main objective of these market-based mechanisms is to make renewables more profitable and carbon-based energy unprofitable for business and investors. The list of policy prescriptions to achieve this includes: pricing carbon as a global tax, establishing trading schemes, the removal of fossil fuel subsidies and allocation of subsidies to cleaner energy production that can be framed as 'green growth'. Mitigation policies that indirectly influence these economic or market conditions include awareness raising (eg. of customers) through information programs, or direct governmental provision of services to foster clean energy, which can include examples from funding research programs to strengthening public transport (Krarup and Russell, 2005).

The policy instruments mentioned above, can contribute to the transition of the EBS. In fact, thanks to the political and regulatory system, several policies already in place in selected countries have contributed to major changes such as emission controls, and the steady rise of wind and solar developments, making them cheaper and more profitable than some fossil fuels in new projects (Pegels and Lütkenhorst, 2014). There are hardly any negative effects associated with implementing or fostering these sets of policies. But we point here to the risks associated with over valuing their capacity for triggering the necessary system transformation. Carbon pricing in particular, currently the most evaluated policy for shifting energy market conditions, represents a powerful signal for internalizing environmental and social costs in the EBS, and holds multiple national motivations to do so (Edenhofer et al., 2015). However, in our conceptual framework it should not be lauded as a 'silverbullet' for system reconfiguration and should be contemplated only in combination with more comprehensive measures (Grubb, 2014). In fact, even if regulators focus on carbon pricing along with the other instruments mentioned above, forming a complementary set, the risk of not achieving a deliberate transformation of the EBS and overshooting climate targets will remain high.

Most notably, these instruments are still not widely and effectively deployed even after several decades of climate science (Giddens, 2009), which has maintained the landscape for carbon majors to retain a resilient market inertia. Our approach considers that an important question to ask is not whether a set of policies can be effective for EBS intervention and reconfiguration, but on whether society can first overcome the forces preventing them from being implemented in the first place. In other words, research and policy needs to ensure that it is tackling the root cause of a problem and not its symptoms. For example, it is understood that rent-seeking influences of business actors can lead to policy failures given they lobby for policies that favour their own self-interest (Helm, 2010; Olson, 1971). Yet, while this factor may account for a fraction of the lack of ambitious policies, other factors are associated to deeper lock-in dynamics (Beddoe et al., 2009).

Besides business model, investment and infrastructure lock-in, a complex system like the EBS is susceptible to multiple technological, political, cultural and psychological lock-in (Scheffer and Westley, 2007; Sydow et al., 2009). The view presented in this work argues that neither the EBS lock-in sources are unidimensional - e.g. from private interest lobbying or infrastructural sunk costs- nor solutions and interventions should be unidimensional -eg. carbon prices and subsidy reforms. However, it grounds on the "simplicity" behind complex systems, where no matter the level of entanglement a system may have, its behaviour is governed by a critical set of processes (Folke et al., 2010).

A major challenge remains even after identifying root processes in system lock-in. In heuristic terms, this can be framed as the notion that it is preferable "not to tackle a problem with the same kind of mindset that initiates it" (A. Einstein). Complexity demands innovative approaches when analysing system interventions. In an age where quantitative thinking is so prevalent, the words of systems thinker Donella Meadows might resound to 
explain some of these underlying challenges: intervening in a system using numerical benchmarks alone (i.e. prices, interest rates, subsidies) is like 're-arranging the deck chairs in the Titanic.' In system dynamics, numbers can be considered the least effective way for radically shifting a system's trajectory (Meadows, 1999).

To contribute an original framework that can give a whole system perspective, we construct a 'metabolic map.' The map follows from the analysis of the EBS as holding a critical role in the context of the combustion metabolic singularity. The motivation for it is to help consolidate and trace the different dynamics at play among and across scales, showing what the system lock-in looks like. Continuing our framework, the metabolic map builds on and extends approaches based on system dynamics in the energy business and corporate law (Dangerman and Schellnhuber, 2013; Dangerman, 2013), Panarchy (Gunderson, 2001), leverage points for system intervention (Meadows and Wright, 2008), and general notions of ecological economics (Arrow et al., 1995). A key advance of the EBS metabolism is that it explores the role of purpose in its corporate governance and the overall system behaviour.

\section{The energy business metabolism: map and regulation}

\subsection{Mapping the energy business metabolism}

We combine the EBS complex system dynamics with the metabolic concept by depicting the stocks and flows of carbon, energy, and financial capital, whilst representing an environmental feedback mechanism acting as a regulatory system. We also illustrate the position of the system's purpose $e^{7}$. We expect that understanding the dynamics in this metabolic map will provide clarity of where the systemic interventions can be made to prevent perpetuation of Earth system damage.

Figure 5 shows our stylized depiction of the EBS metabolism. It represents the result of our thought process and can be used as a navigational tool for the structure of analysis that follows in sections 4.1 through 4.4. A more detailed description of how and what each element represents as well as the methodology used to construct it, particularly in relation to stock and flow of financial capital, can be found in Appendix 1 and SM2. Abduction is used to manage the consolidation of multiple frameworks, disciplines, components and dynamics evaluated.

The general overview of Figure 5 is a birds-eye representation of the right side of Fig 2 and shows a positive feedback loop between outflow-inflow of financial capital linked to the transformation of carbon sources to $\mathrm{CO}_{2}$, and its environmental signal returning back to the EBS. Using this metabolic map as a basis, we analyse three governing dynamics of complex systems ${ }^{8}$. First, positive feedbacks, since they reinforce a specific trajectory and behaviour, which applied to the EBS context are dynamics of increasing business returns. Second, the environmental feedback mechanism, which includes stabilizing effects from negative feedbacks as well as those that prompt systemic shifts by improving conditions for competing feedback loops (eg. a low carbon EBS). And finally, the system driver or goal, which acts as an internal regulator of behaviour and direction, and is framed as the business purpose. These are therefore critical areas to analyse intervention for lock-in release and system transformation.

\footnotetext{
7 We recall an important clarification on language made by Meadows and Wright (2008): "The word function is generally used for a nonhuman system, the word purpose for a human one, but the distinction is not absolute, since so many systems have both human and nonhuman elements."

${ }^{8}$ This analysis is based on a thorough review of the literature, both directly related to the energy and climate sector, or indirectly related but relevant to the dominant business systems paradigm present in the EBS. We focus predominantly on corporate law and management literature, but recognize as limitation that this might not be exhaustive; unidentified and relevant bodies of literature from the business and management sector could be still be considered in this analysis.
} 

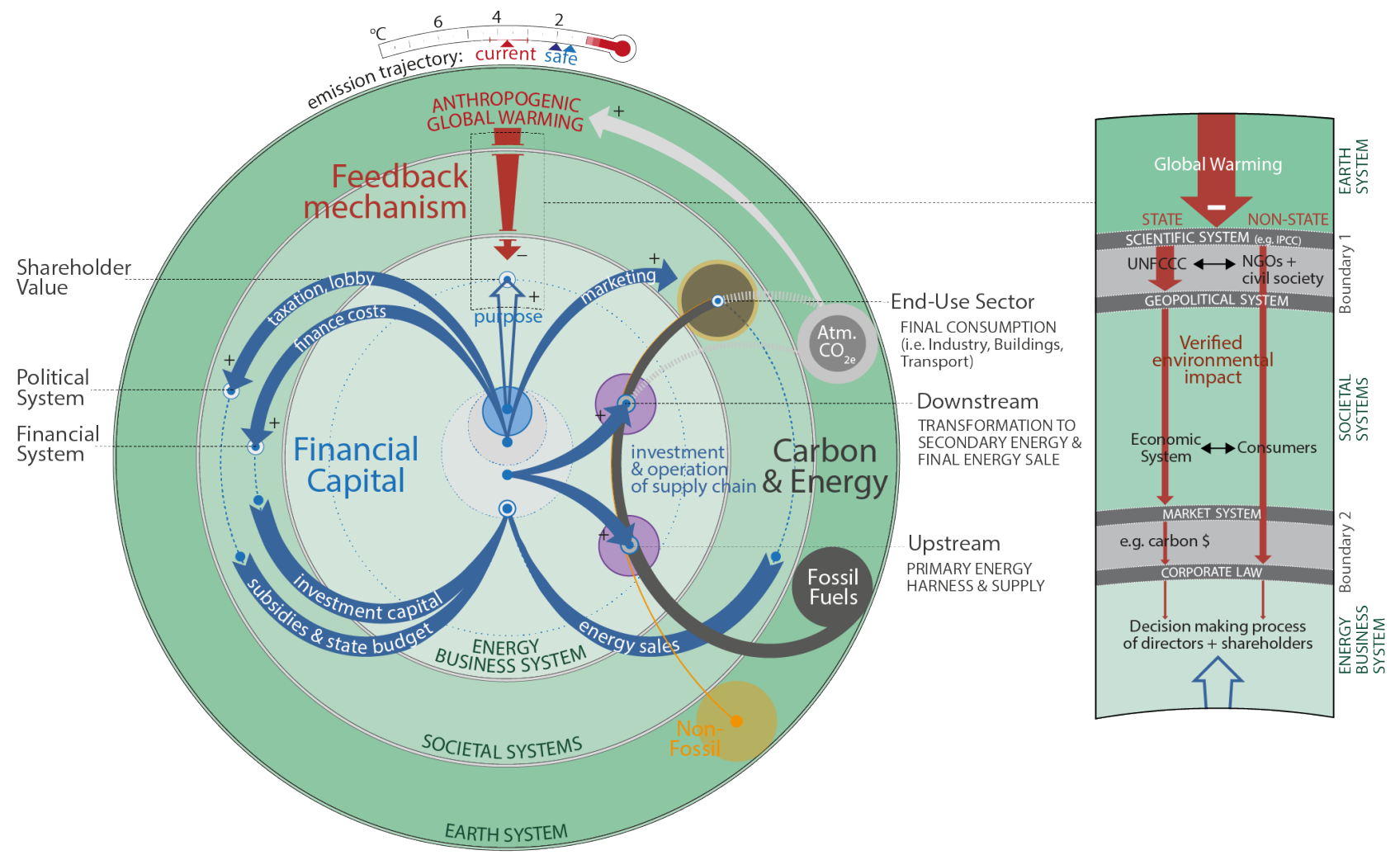

Legend:

Stock \& Flow of Financial Capital

Shareholder Value ..

(equity +
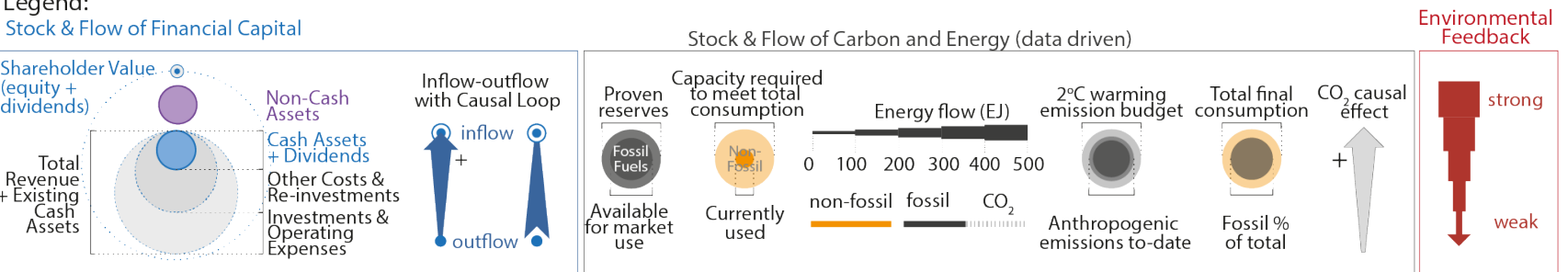

Fig. 5. The Energy Business Metabolism. Illustration of the energy business system in the form of stock and flow of carbon, energy and financial capital, the system's purpose or internal drive influencing behavior and trajectory, and the process of reception of environmental signals resulting from side effects in its activity (see Appendix and Supplementary material sections for further explanation of the method and logic of the diagram). a) The diagram represents a bird's eye view of the aggregate combustion metabolism shown in Fig. 2, with specific of depiction dynamics across nested system scales. For a more detailed depiction and description of this metabolic construct, see appendix 1. b) A zoom-in stylized representation of the environmental feedback mechanism (red arrow) for anthropogenic climate change. The Earth system signal pathway travels across general societal systems into the decision-making process of directors and shareholders, which governs the trajectory of the business system. The crossing of multiple system boundaries is also represented here as filters that qualitatively decrease the signals' strength and fidelity.

\subsection{Positive feedbacks: Increasing business returns}

Positive feedbacks are represented in Fig. 5a by the stocks and flows of financial capital, with inflows and outflows as causal loops collectively affecting the flow of carbon in the energy supply chain. Positive feedbacks are a common approach to explain lock-in and path dependency of business systems in general, and for specific properties of the EBS (Aghion et al., 2014; Arthur, 1989; Dangerman and Schellnhuber, 2013). The business system employs its revenue for its basic operating expenses (i.e. including cost of goods sold), keeping the system running (akin the catabolic process in biological systems), and also re-invests in its own growth and security within its environment (akin the anabolic process in biological systems). Positive feedbacks exist with outflow to specific societal systems given they regulate business conditions that stimulate corporate revenue. Namely, we highlight the political and financial systems, and the end-use sector. A focus on system efficiency (i.e. maximizing output with least input) intensifies these loops, producing reinforcing effects to its current trajectory. For example, the IT revolution was instrumental in maximizing efficiency and increasing reserves for the EBS (Arthur, 1996; Dangerman and Schellnhuber, 2013). We summarize below the feedback dynamics with these three groups: 
a. Financial capital flows from the EBS to the Political system in the form of taxes and lobbying. These have a positive feedback on the backflow, which occurs in the form of subsidies. Subsidies increase competitive advantage over the alternative energy system through dynamics of 'Success to the Successful' (Fig. 3b). Fossil fuel subsidies directly enable EBS investments that can overshoot a $2^{\circ} \mathrm{C}$ carbon budget (Erickson et al., 2017). Higher outflows to the political system can affect culture and values through economic development and improve organization legitimacy (Tang and Koveos, 2008). Regulatory conditions (legal system) that have a positive effect on revenue flow are also increased by this dynamic since they are controlled by the political system. Lobbying, contributes to allocation of subsidies, but also to the loss of adaptability by maintaining the status quo of legal conditions, resisting any regulatory changes that might affect inflows, outflow or competitive advantages negatively (Danielsen, 2005; Helm, 2010). This form of outflow and organizational power, particularly high in the EBS, whilst allowing firms to design their environment for their own benefit, reduces the capacity to sense other changes in their environment (Levinthal and March, 1993). This form of myopia distorts susceptibility and hence limits the effectiveness and fidelity of the environmental feedback mechanism (i.e. second boundary layer of Fig $5 b$ ).

b. The relationship between the energy business and the Financial system can be characterized by a steady strategic partnership (Boyd, 2014; Mintz and Schwartz, 1983; Perez, 2003). The behaviour and function of firms in modern industrial societies evolved closely with those of the financial system and the contract reforms used to raise funds in capital markets (Greenwald and Stiglitz, 1992). Stable profits from the conventional energy system encourage investments from the financial sector. An increase in available capital helps fund the capital-intensive energy infrastructure, which facilitates lock-in at the techno-infrastructural level. Demands for short-term profit from financial investors affects the decision making process of directors (Crotty, 2003) (see Fig. 3a). However, unlike other industrial sectors, the EBS is particularly characterized by internal financing through retained earnings given the economic size of its carbon majors - specially in IOCs, allowing them to have higher degrees of independence from the financial system (GEA, 2012; IEA, 2014).

c. Specific marketing practices affect the consuming behaviour of the End-use sector. These include any influence to customers incentivizing higher rates of consumption, raising the profile of the individual business, the products and services produced, and the minimization of the severity of side effects caused by product consumption. Marketing (business-to-business (B2B) and business-to-customer (B2C)) is employed to sustain energy demand, which has a direct effect on maintaining sales inflows. Documented examples include strategic B2B cooperation between the EBS and other business actors of the transport sector (Mintz and Schwartz, 1981; Wilson, 1975). The sponsoring of climate scepticism and lack of transparent communication of climate impacts performed by fossil-based firms is included in this form of marketing (Oreskes and Conway, 2011; Supran and Oreskes, 2017). Both of these re-investments (i.e. B2B and B2C) have a direct positive influence on gross profits and maintenance of organizational legitimacy towards society (Dowling and Pfeffer, 1975).

\subsection{Negative feedbacks: Environmental feedback mechanism}

Dangerous anthropogenic global warming is detected by the scientific (eg. IPCC) or Earth monitoring system, triggering feedback signals that can be divided into two types of channels: a formal or state-level channel, and an informal non-state broader public one. The state level holds more bureaucratic chains of commands and communication with eventual legislative repercussions. The non-state one holds looser constraints through multiple communication venues (e.g. NGOs, social media etc.). These essentially represent two general types of formal and informal pressures a business system receives. For the EBS, the main signal received can be translated as 'dangerous climate change is produced as a side-effect of the combustion of your product,' and it is a negative feedback because it implies stopping or reducing the intensity of a specific system behaviour. Our interpretation, as described below, shows that by the time the feedback arrives to the decision-making level of the EBS, however, its intensity is significantly reduced in a process that first crosses the boundary between the environmental and societal systems, and then by that between the business and its outer societal systems (Rosen-Zvi, 2011).

In a biological system, external signals are received in the system's boundary (e.g. cellular membrane), interpreted and translated for internal compensations to maintain homeostasis and adaptability to environmental changes. Likewise, we depict the Earth, societal and EBS boundaries as metaphors for layers where legal and other regulatory systems operate, shown in further detail in Fig $5 \mathrm{~b}$, and described below.

\subsubsection{First boundary layer: Earth to societal system}


This boundary layer has its membrane-like function executed both by the scientific system and geopolitical regulations. The scientific system is responsible for quantifying emissions and the extent of climate impact, and communicating appropriate signals to societal levels for proper actions. In the state-level channel, organizations like the UNFCCC act as intermediaries between the scientific system and the geopolitical system that can subsequently produce formal regulations in the national or international economic system. In non-state channels, organizations such as independent NGO's, civil society groups and broader media accelerate communications and awareness to the wider society. Although the scientific system is successful in developing and transmitting environmental signals (e.g. through IPCC reports), these are not promptly assimilated with high fidelity by the geopolitical nor the economic system - considering for example slow processes of UNFCCC and national policies on political economy (Bushell et al., 2015; Roberts and Parks, 2006). Multiple sociological dynamics (eg. psychology, techno-economic inconvenience, misinformation, etc.) are also involved in the slow and heterogeneous response of energy customers to the scientific signal (Giddens, 2009).

\subsubsection{Second boundary layer: Societal to energy business system}

The second boundary layer lies between the collection of societal systems and the EBS. Here, the regulatory membrane is executed by the market system and the corporate legal system, which function as recipients and translators of the signal on verified environmental impacts of greenhouse gas emissions to the EBS.

a. Market system. Here the system specifically embodies energy, environmental and carbon market dynamics. It provides feedback to the EBS through official market regulations via the state channel, such as technological or emission standards, taxation of carbon, emission trading schemes, and any other taxation or subsidy allocation policy. Non-state market signals that belong to this boundary are normal supply-demand and pricing forces, as well as deliberate changes in customer practices due to increased environmental awareness, such as ethical consumption and investment practices.

The degree market by which signals and regulations have impacted the EBS with respect to global warming is varied and disputed. Efficiency standards, perhaps the more ubiquitous official approach, have had successful experiences but also produced rebound effects (Sorrell, 2007). Emission trading schemes have had similar ambiguous results, although tested in a more reduced set of countries and jurisdictions than environmental standards (Betz and Sato, 2006; Helm, 2010). Carbon pricing, on the other hand, has been one of the least applied policies, also with mixed results in early experiences (Aldy and Stavins, 2012). However, it has attracted increasing attention and political traction thanks to multiple reports by leading economists, which in itself can be considered a form of feedback to the EBS. This informal pressure perhaps influenced some of its large actors to incorporate so called "shadow" carbon prices in their internal operations (CPLC, 2017). While some state policies have had some successful negative feedback regulations to the EBS, stabilizing and even reducing of fossil-based sources in supply chains, (eg. Germany's Energiewende (Jacobsson and Lauber, 2006)), these are still associated to specific niches and hardly to a transforming effect in the global EBS regime. Supply and demand macroeconomic effects on energy prices have responded to general market dynamics rather than to deliberate climate change signals (Hamilton, 2011; Krichene, 2002). Customer preferences, whilst progressively responding to environmental concerns do not seem to pose a radical feedback on the EBS towards climate target consistent projections (IEA, 2016c).

Consumer disclosure laws that require vivid communication of a product's side-effect to customers at the point of sale, are not developed nor enforced for products sold by the EBS that contribute to the greenhouse effect. By using a comprehensible format to explain the externalities associated with fuel consumption, analogous to tobacco disclosure laws, such intervention would act as a deflector of the environmental signal to the EBS, pushing the liability back to customers. This would reduce imperfections from asymmetries of information flow by allowing a more informed and constantly reminded customer; shifting market demand behaviour (Cohen and Viscusi, 2012; Loewenstein et al., 2014).

b. Corporate Law. This represents the closest regulatory membrane to the EBS, forming the boundary of incorporated organizations, and focuses specifically on shareholder's liabilities and director's fiduciary duties with regard to environmental feedback from global warming. In light of environmental impacts as side effects of its products, duties and liabilities affect the decision-making process in evaluating radical business model reconfigurations to prevent them. However, analysing the role of corporate law requires clear distinction between the three main types of actors within the EBS: IOCs, NOCs and nation states. In 
terms of shareholder liabilities, IOCs and NOCs alike have limited exposure of personal assets to any grievance, which acts as an attenuator of the environmental feedback mechanism (Dangerman and Schellnhuber, 2013). NOCs, however, have the added symbolic difference that a nation state is a majority shareholder. Nation states conducting the energy business without the construct of incorporated entities, such as China, do not fall within corporate legal duties and liabilities but are subject to international law and principles embodied in the United Nations. In all three cases, shareholders personally face mild consequences, if any at all, on any form of wrong from lack of appropriate climate action (Wallace, 2008). In other words, shareholders are unlikely to be sued because their companies did not perform appropriate actions to prevent climate change. Benjamin (2016) particularly argues that this legal context is what allows carbon majors to cite concern about climate change but not make dramatic efforts to reduce their associated emissions. Furthermore, the concept of 'appropriate climate action' can have a high degree of legal and technical ambiguity on business actors.

In terms of director's fiduciary duties, publicly traded IOCs and NOCs in an Anglo-Saxon context must follow securities laws that requires disclosure of all environmental information that can have a 'reasonably likely material effect on the company', while those that are closely held have no prescribed public disclosure requirement (Wallace, 2009). In general, for all IOCs and NOCs, the broader legal concept of director's duties is to act in good faith and apply the best business judgement. Neither securities law nor the 'best business judgement' rules have, so far, established a clear legal basis for litigation to the EBS based on climate change inaction (Wallace, 2008). Ongoing litigations relate to companies knowingly creating climate change uncertainty in the public (McWilliams, 2017). We can infer from this that the corporate legal regulatory system does not impose limitations here, let alone be conducive to trigger the radical business system reconfigurations needed to prevent net costs on society and the Earth system. Furthermore, any enforcement or experimentation at a local level is ultimately susceptible to jurisdictional leakage from the broader challenge of global EBS regulation: the lack of an international regulatory body (Stiglitz, 2007).

\subsection{System driver: Business purpose}

The environmental feedback mechanism described above represents a regulatory system external to the EBS that governs the fidelity, intensity and enforceability of how the Earth's feedback signals are perceived. The business purpose, on the other hand, represents an internal regulatory system that governs the rate and direction of business actions (i.e. its metabolic activity) based on positive and negative feedbacks evaluated internally. Purpose is framed here as the EBS's behavioural driver or system goal, essentially the internal motivator for action and existence. Business purpose, as a systemic concept, encompasses both corporate law, in statutes and legal forms of governance, but also in general social norms and business culture, with both elements being interdependent (Fisch, 2005). We thus structure our analysis considering these two dimensions.

\subsubsection{Shareholder's legal primacy?}

A commonly held belief is that the purpose of business is the maximization of profit and catering to the best interest of the company and shareholders. The liabilities and duties of managers and directors are thus thought to be governed by this canon. A system analysis requires evaluating the degree of influence that shareholder's profit primacy, both from a corporate legal and a cultural lens, has on the EBS decision-making process in the context of undisputed climate change. In other words, to what extent can EBS managers and directors make radical stakeholder considerations, executing transformative business model decisions that may have adverse repercussions on short-term profit scenarios - e.g. from stranded assets and first mover's disadvantage (Jotzo and Mazouz, 2015; Kolk and Levy, 2001)? In a decision-making process regarding the core business model strategy, is the shareholder profit paradigm a stronger weight than consistency with Earth system resilience? Or is the EBS governance reality more ambiguous than what this straightforward scenario presents? If we consider the present emission trajectory and forecasts of the EBS, these questions should become increasingly critical since curbing emissions to meet an ambitious $1.5^{\circ} \mathrm{C}$ target implies radical and unprecedented business decisions such as the opportunity cost of unburned carbon assets (McGlade and Ekins, 2015).

In legal and academic terms, the level of agency of shareholder primacy has been an intense and still ongoing debate, particularly in Anglo-Saxon contexts (Bainbridge, 1993; Stout, 2012). The debate has predominantly focused on specific case studies, and on the issue of whether shareholders can in fact sue directors for partially favouring other stakeholders (e.g. the Earth system) at their monetary expense (Murray, 2012). Examples used by 
scholars in this dispute include historic litigation cases like Dodge vs Ford regarding dividend distribution policies, Revlon vs MacAndrews Holding regarding duties to shareholders, and cases of shareholder primacy that didn't escalate to litigation but affected an acquisition decision, such as with the case of Ben \& Jerry's takeover by Unilever. These and other examples have been used in the growing rhetoric that the conventional legal form of incorporation, i.e. the limited liability company, is not fit-for-purpose if managers are to pursue social and environmental goals alongside and/or above economic ones in specific cases such as Earth system damage (Clark Jr and Babson, 2011; Mickels, 2009). This debate, in fact, has been significant in influencing a so-called revolution in corporate law in the USA and Europe since the 2008 financial crisis, giving rise to innovative legal forms such as the benefit corporation, the flexible purpose corporation or the community interest corporation, to name a few (Esposito, 2012). Nevertheless, in strict legal terms, several scholars still argue that courts-at least Anglo-Saxon ones-significantly protect managers if they are to make social and environmental considerations, in detriment to short-term shareholder profit, as long as they apply good faith and their best business judgement (Mickels, 2009; Wallace, 2009). In practice, new empirical studies show a direct correlation between cultures with high belief on shareholder primacy and higher carbon emissions (Kock and Min, 2016).

\subsubsection{Business' normative purpose}

On the other hand, if business culture and norms are factored in alongside legal constraints, the extent to which shareholder's profit governs business trajectories is reinforced (Fisch, 2005). Our analysis points to at least three reasons why EBS's managers face unfavourable governance conditions to propel radical business model transformations despite unequivocal climate change. First, considering the ongoing legal debate on shareholder primacy, the fact that managers are not necessarily experts in the matter, and that courts still have freedom of interpretation, managers and directors will tend to remain averse to risk (Murray, 2012). Due to fiduciary breach, shareholders can still sue them, or fire them (Murray, 2011). Second, large firms such as those belonging to the EBS rarely have one single shareholder voice or position for directors to evaluate (Stout, 2012). Given shareholder's interests are varied, including a minority that favour radical considerations on issues like clean energy, directors may apply least common denominator decisions that tend to favour more 'activist' or depersonalized shareholders demanding sustained returns (Dore, 2008; Grossman and Stiglitz, 1980). Third, directors and shareholder in large corporations are likely to share mindsets. Directors and managers are chosen and rewarded by shareholders and notably, more often than not are shareholders due to executive compensation schemes; a factor that can produce distorted incentives in high-level strategic decisions (Dangerman, 2013; Dore, 2008; Stiglitz, 2002).

There are at least two main clarifications that need to be made regarding a systems characterization of the EBS purpose. The first is that, for the purpose of this work, we assume here a similar self-interested behaviour across nation states, nationally owned and investor owned companies. Shareholder primacy dynamics apply particularly to publicly traded firms, and this is regardless of whether these are IOCs or NOCs. But this does not imply that all firms make decisions consistent with the same economic principles. In fact, they can exhibit what can be considered irrational behaviour based on a neoclassical model (Lyon and Maxwell, 2008). We acknowledge that business is not a single decision-making system seeking short-term profit-maximization, but in the myriad of internal dynamics and actors, the prevailing purpose is one oriented to maximizing self-interest. While in IOCs this fulfils the self-interest of individuals or institutional investors, in NOCs and states they tacitly or explicitly maximize the national agenda set by its specific political context; remaining susceptible to both 'free-riding' actions as well as 'political swings' (Stavins R. and K. Ramakrishna, 2014). Although the case can be made that countries have increasingly adopted business-like practices and motives (Michaels, 2014), we recognize this may require a more specified analysis.

A second important clarification is that we address the element of purpose in the business model as separate to the value proposition. Business models are recognized as a "market device" that, through a static configuration of elements outline the value of the product or service offered by a firm (i.e. the value proposition), and the processes to create and capture this value (Zott et al., 2011). The value proposition is thus a core element of the business model, and for the EBS it can be generally described as 'the reliable delivery of energy at an affordable price.' Revisiting and shifting the value proposition - at a firm or a whole industry level — normally changes the relationship with the customer, for example in a joint value creation or in product-service systems. A change in value proposition is fundamental to business model innovation and can be a source of competitiveness (Wainstein and Bumpus, 2016). In simple terms, the business model explains how an organization makes money 
(Osterwalder, 2004), whilst the business purpose addresses why a business makes money or exists in the first place. A revision and shift at the business purpose level is related to social innovation (Phills et al., 2008).

\section{Concluding remarks}

This work represents a mapping exercise and analysis of key Earth and EBS dynamics, including purpose. It is intended as a contribution to insights in Earth system management, irrespective of implicit methodology gaps that can arise from its broad scope. Fundamentally, the application of systems thinking to a holistic metabolic map illustrates why the EBS may have a disturbingly unfavourable condition to deal with Paris' ambitious climate targets and is locked-into further loss of Earth system resilience. This comes both from information filters that reduce its capacity to receive and act accordingly to proper environmental feedback signals and, more importantly, because of its fundamental systems purpose that conditions motivations in its decision-making. As such, we believe this work presents systemic reasons to hypothesise that the current for-profit shareholder maximisation purpose of the energy business complex is incompatible with avoiding dangerous climate change. If this is so, it introduces an unprecedented systemic challenge since it relates to a core identity of the system, whose shift may not be easily produced by external interventions and instead require a change in its fundamental governance. It further suggests that while economic internalizations such as carbon pricing can help as an element in a transition, they may fall short of the needed transformation towards a truly resilient human-Earth relationship.

We provide here two suggestions that can be considered by researchers, business and policymakers alike given the insights presented. First, the systemic issues raised require much more attention and research in the present climate agenda. Business interests and their implicit tensions with climate change are hardly explicitly addressed by UNFCCC or by the IPCC compiled bodies of literature ${ }^{9}$. The high stakes to achieve EBS transformation in an unprecedented narrow timeframe do not allow relying on solutions that may arise from lock-in mindsets; they demand radically innovative approaches that need to be proposed and evaluated. Furthermore, this paper validates ongoing societal reactions, initial changes in corporate law and a growing entrepreneurial niche demanding a planet-people-profit prioritization in governance (Huffington, 2013; Wilson and Post, 2013). Actual validation the EBS metabolic model with quantitative methods remains an important next step beyond this conceptual work. Additionally, while this paper focused on introducing an interdisciplinary and systems-based framework, a more directed business and management analysis on the insights derived from the EBS might also be a valuable continuation to this work.

Second, we suggest that individual energy businesses, particularly carbon majors, should present business model transition strategies that are consistent with $1.5^{\circ} \mathrm{C}-2^{\circ} \mathrm{C}$ climate targets and their associated carbon budgets. This suggestion builds from the successful approach leading to the Paris agreement. It has been argued that one of the main reasons for the success of the UNFCCC Paris agreement has been its combined bottom-up and topdown approach (Chan, 2016). By requesting parties to present their intended nationally determined contributions (INDCs) to climate targets, without any specific prescription, it allowed for a bottom-up approach that facilitated the dialogue in the lead up to Paris and its initial plenaries. We thus suggest a similar approach can be taken for EBS actors. By presenting their climate-proof business model transition pathways, energy business actors can be explicit in their Earth system stewardship and ground on the fact that society is the ultimate licensor for business. Corporate determined contributions to climate targets could include business transformation pathways and the required support from the societal system to achieve them, keeping as a basis long-term Earth system resilience, which ultimately aligns with business stability. Using the Earth system as a benchmark is important, since business strategies that satisfy current generations while shifting risk to future ones - such as increasing present fossil fuel infrastructure lock-in while investing in future roll-outs of negative emission technologies- could be perceived as moral hazard.

The EBS and its carbon majors have grown into supranational systems, and yet there is at present no official supranational venues to properly engage, discuss and regulate their business models. A mixed bottom-up approach to EBS transformation requires filling this accountability gap and may include official involvements with multilateral bodies such as the UN. In short, we suggest the EBS should undergo a transformation in its corporate governance towards Earth system governance.

\footnotetext{
${ }^{9}$ Consider for example that the Paris agreement makes no mention of fossil fuels (UNFCCC, 2015a), supranational business actors are not given a defined seat in UNFCCC negotiations, and IPCC wg3 does not compile significant knowledge on how business systems can contribute to lock-in and tamper advance of mitigation policies (IPCC, 2014).
} 


\section{References}

Aghion, P., Hepburn, C., Teytelboym, A., Zenghelis, D., 2014. Path dependence, innovation and the economics of climate change. Centre for Climate Change Economics and Policy/Grantham Research Institute on Climate Change and the Environment Policy Paper \& Contributing paper to New Climate Economy.

Aldy, J.E., Stavins, R.N., 2012. The promise and problems of pricing carbon: theory and experience. The Journal of Environment \& Development 21, 152-180.

Arrow, K., Bolin, B., Costanza, R., Dasgupta, P., Folke, C., Holling, C.S., Jansson, B.-O., Levin, S., Mäler, K.-G., Perrings, C., 1995. Economic growth, carrying capacity, and the environment. Ecological economics 15, 91-95.

Arthur, W.B., 1989. Competing technologies, increasing returns, and lock-in by historical events. The economic journal, 116-131.

Arthur, W.B., 1996. Increasing Returns and the Two Worlds of Business. Harvard business review 74, 100-109.

Arthur, W.B., Ermoliev, Y.M., Kaniovski, Y.M., 1987. Path-dependent processes and the emergence of macro-structure. European journal of operational research 30, 294-303.

Ayres, R.U., 1989. Industrial metabolism. Technology and environment 1989, 23-49.

Bainbridge, S.M., 1993. In defense of the shareholder wealth maximization norm: A reply to Professor Green. Wash. \& Lee L. Rev. 50, 1423.

Bale, C.S.E., Varga, L., Foxon, T.J., 2015. Energy and complexity: New ways forward. Applied Energy 138, 150-159.

Barclays, 2013. Global E\&P Spending Outlook, in: Research, B.E. (Ed.), E\&P Spending Outlook, New York \&

London.

Beddoe, R., Costanza, R., Farley, J., Garza, E., Kent, J., Kubiszewski, I., Martinez, L., McCowen, T., Murphy, K., Myers, N., 2009. Overcoming systemic roadblocks to sustainability: The evolutionary redesign of worldviews, institutions, and technologies. Proceedings of the National Academy of Sciences 106, 2483-2489.

Benjamin, L., 2016. The Responsibilities of Carbon Major Companies: Are They (and Is the Law) Doing Enough? Transnational Environmental Law 5, 353-378.

Betz, R., Sato, M., 2006. Emissions trading: lessons learnt from the 1st phase of the EU ETS and prospects for the 2nd phase. Taylor \& Francis.

Bidmon, C.M., Knab, S.F., 2018. The three roles of business models in societal transitions: New linkages between business model and transition research. Journal of Cleaner Production 178, 903-916.

Bjørn, A., Bey, N., Georg, S., Røpke, I., Hauschild, M.Z., 2017. Is Earth recognized as a finite system in corporate responsibility reporting? Journal of Cleaner Production 163, 106-117.

Bower, J.L., Paine, L.S., 2017. The error at the heart of corporate leadership. Harvard Business Review 95, 50-60.

Boyd, R., 2014. Energy and the financial system: what every economist, financial analyst, and investor needs to know. Springer Science \& Business Media.

BP, 2016. Outlook to 2035, in: Dale, S. (Ed.), BP Energy Outlook. British Petroleum, http://www.bp.com/en/global/corporate/energyeconomics/energy-outlook-2035.html.

BP, 2017. 2017 Energy Outlook, in: Dale, S. (Ed.), BP Energy Outlook. British Petroleum plc, London, England.

Brienen, R.J.W., Phillips, O.L., Feldpausch, T.R., Gloor, E., Baker, T.R., Lloyd, J., Lopez-Gonzalez, G., Monteagudo-Mendoza, A., Malhi, Y., Lewis, S.L., 2015. Long-term decline of the Amazon carbon sink. Nature 519, 344-348.

Bruckner T., I.A.B., Y. Mulugetta, H. Chum, A. de la Vega Navarro, J. Edmonds, A. Faaij, B. Fungtammasan, A. Garg, E. Hertwich, D. Honnery, D. Infield, M. Kainuma, S. Khennas, S. Kim, H.B. Nimir, K. Riahi, N. Strachan, R. Wiser, and X. Zhang, 2014. Energy Systems, in: Edenhofer, O., R. Pichs-Madruga, Y. Sokona, E. Farahani, S. Kadner, K. Seyboth, A. Adler, I. Baum, S. Brunner, P. Eickemeier, B. Kriemann, J. Savolainen, S. Schlömer, C. von Stechow, T. Zwickel and J.C. Minx (eds.) (Ed.), Climate Change 2014: Mitigation of Climate Change. Contribution of Working Group III to the Fifth Assessment Report of the Intergovernmental Panel on Climate Change, Cambridge University Press, Cambridge, United Kingdom and New York, NY, USA.

Bumpus, A., Comello, S., 2017. Emerging clean energy technology investment trends. Nature Climate Change 7, 382-385.

Bushell, S., Colley, T., Workman, M., 2015. A unified narrative for climate change. Nature Climate Change 5, 971-973.

Carpenter, S., Brock, W., 2008. Adaptive capacity and traps. Ecology and society 13.

Chan, N., 2016. Climate Contributions and the Paris Agreement: Fairness and Equity in a Bottom-Up Architecture. Ethics \& International Affairs 30, 291-301.

Christoph, B., Nils, J., Gunnar, L., Keywan, R., Morna, I., Jiyong, E., 2015. Carbon lock-in through capital stock inertia associated with weak near-term climate policies. Technological Forecasting and Social Change 90, Part A, 62-72.

Clark Jr, W.H., Babson, E.K., 2011. How benefit corporations are redefining the purpose of business corporations. Wm. Mitchell L. Rev. $38,817$.

Cohen, M.A., Viscusi, W.K., 2012. The role of information disclosure in climate mitigation policy. Climate Change Economics 3, 1250020. CPLC, 2017. Report of the High-Level Comission on Carbon Prices, in: Coalition, C.P.L. (Ed.).

Crotty, J., 2003. The neoliberal paradox: The impact of destructive product market competition and impatient finance on nonfinancial corporations in the neoliberal era. Review of Radical Political Economics 35, 271-279.

Croucher, M., 2011. Potential problems and limitations of energy conservation and energy efficiency. Energy Policy 39, 5795-5799.

Dangerman, A.T.C.J., Schellnhuber, H.J., 2013. Energy systems transformation. Proceedings of the National Academy of Sciences 110, E549-E558.

Dangerman, J., 2013. The Energy System, Lock-In and Adaptation. Radboud University Nijmegen, Nijmegen, Netherlands.

Danielsen, D., 2005. How corporations govern: Taking corporate power seriously in transnational regulation and governance. Harv. Int'l LJ 46, 411.

David, P.A., 2001. Path dependence, its critics and the quest for 'historical economics'. Evolution and path dependence in economic ideas: Past and present 15, 40 .

de Molina Navarro, M.G., Toledo, V.M., 2014. The Social Metabolism: A Socio-ecological Theory of Historical Change. Springer.

De Stercke, S., 2014. Dynamics of energy systems: A useful perspective. 
Diamond, J.M., 2006. Collapse: How Societies Choose to Fail Or Succeed. Penguin.

Dore, R., 2008. Financialization of the global economy. Industrial and Corporate Change 17, 1097-1112.

Dosi, G., 1982. Technological paradigms and technological trajectories: a suggested interpretation of the determinants and directions of technical change. Research policy 11, 147-162.

Dowling, J., Pfeffer, J., 1975. Organizational Legitimacy: Social Values and Organizational Behavior. The Pacific Sociological Review 18, 122-136.

Edenhofer, O., Jakob, M., Creutzig, F., Flachsland, C., Fuss, S., Kowarsch, M., Lessmann, K., Mattauch, L., Siegmeier, J., Steckel, J.C., 2015. Closing the emission price gap. Global environmental change 31, 132-143.

Erickson, P., Down, A., Lazarus, M., Koplow, D., 2017. Effect of subsidies to fossil fuel companies on United States crude oil production. Nature Energy.

Esposito, R.T., 2012. Social Enterprise Revolution in Corporate law: A Primer on Emerging Corporate Entities in Europe and the United States and the Case for the Benefit Corporation, The. Wm. \& Mary Bus. L. Rev. 4, 639.

ExxonMobil, 2017. Outlook for Energy: A view to 2040, Outlook for Energy, Irvingm, Texas.

Figueres, C., Schellnhuber, H.J., Whiteman, G., Rockström, J., Hobley, A., Rahmstorf, S., 2017. Three years to safeguard our climate. Nature 546, 593-595.

Fisch, J.E., 2005. Measuring efficiency in corporate law: The role of shareholder primacy. J. Corp. 1. 31, 637.

Fischer-Kowalski, M., Weisz, H., 1999. Society as hybrid between material and symbolic realms: Toward a theoretical framework of societynature interaction.

Folke, C., Carpenter, S.R., Walker, B., Scheffer, M., Chapin, T., Rockström, J., 2010. Resilience thinking: integrating resilience, adaptability and transformability. Ecology and Society 15, 20.

GEA, 2012. Global Energy Assessment - Toward a Sustainable Future, Cambridge University Press, Cambridge, UK and New York, NY, USA and the International Institute for Applied Systems Analysis, Laxenburg, Austria.

Geels, F.W., 2002. Technological transitions as evolutionary reconfiguration processes: a multi-level perspective and a case-study. Research Policy 31, 1257-1274.

Geels, F.W., 2014. Regime Resistance against Low-Carbon Transitions: Introducing Politics and Power into the Multi-Level Perspective. Theory, Culture \& Society 31, 21-40.

Geels, F.W., Kemp, R., 2006. Transitions, transformations and reproduction: dynamics in socio-technical systems. Oxford, pp. $227-256$.

Giddens, A., 2009. The politics of climate change. Cambridge, UK.

Goulder, L.H., Parry, I.W., 2008. Instrument choice in environmental policy. Review of environmental economics and policy 2, 152-174.

Greenwald, B., Stiglitz, J.E., 1992. Information, Finance, and Markets The Architercute of Allocative Mechanisms. Industrial and Corporate Change 1, 37-63.

Grossman, S.J., Stiglitz, J.E., 1980. Stockholder unanimity in making production and financial decisions. The Quarterly Journal of Economics, 543-566.

Grubb, M., 2014. Planetary economics: energy, climate change and the three domains of sustainable development. Routledge.

Gruner, R.L., Power, D., 2017. Mimicking natural ecosystems to develop sustainable supply chains: A theory of socio-ecological intergradation. Journal of Cleaner Production 149, 251-264.

Gunderson, L.H., 2000. Ecological resilience--in theory and application. Annual review of ecology and systematics, 425-439.

Gunderson, L.H., 2001. Panarchy: understanding transformations in human and natural systems. Island press.

Gütschow, J., Jeffery, M.L., Gieseke, R., Gebel, R., Stevens, D., Krapp, M., Rocha, M., 2016. The PRIMAP-hist national historical emissions time series. Earth System Science Data 8, 571.

Hamilton, J.D., 2011. Historical oil shocks. National Bureau of Economic Research.

Heede, R., 2014. Tracing anthropogenic carbon dioxide and methane emissions to fossil fuel and cement producers, 1854-2010. Climatic Change 122, 229-241.

Heede, R., Oreskes, N., 2016. Potential emissions of CO2 and methane from proved reserves of fossil fuels: An alternative analysis. Global Environmental Change 36, 12-20.

Helm, D., 2010. Government failure, rent-seeking, and capture: the design of climate change policy. Oxford Review of Economic Policy 26, $182-196$.

Holland, J.H., 1992. Complex adaptive systems. Daedalus, 17-30.

Holling, C.S., 2001. Understanding the complexity of economic, ecological, and social systems. Ecosystems 4, 390-405.

Holling, C.S., Gunderson, L.H., 2002. Resilience and adaptive cycles. Panarchy: Understanding transformations in human and natural systems, 25-62.

Huffington, A., 2013. People, Planet, Profit: Introducing the B Team, in: Post, H. (Ed.), Huffington Post, http://www.huffingtonpost.com/arianna-huffington/people-planet-profit-intr b 3432011.html.

IEA, 2014. World Energy Investment Outlook, in: (OECD), I.E.A.I.o.t.O.f.E.C.a.D. (Ed.), Energy Investment Outlook to 2035. OECD/IEA, Paris, France.

IEA, 2016a. CO2 emissions from fuel combustion, in: (OECD), I.E.A.I.o.t.O.f.E.C.a.D. (Ed.), Energy Statistics, Paris, France.

IEA, 2016b. World Energy Investment 2016, in: (OECD), I.E.A.I.o.t.O.f.E.C.a.D. (Ed.), Energy Investment. OECD/IEA, Paris, France.

IEA, 2016c. World Energy Outlook 2016, in: (OECD), I.E.A.I.o.t.O.f.E.C.a.D. (Ed.), World Energy Outlook, Paris, France.

IEA, IRENA, 2017. Perspectives for the Energy Transition.

IPCC, 2014. Summary for Policymakers, in: Edenhofer, O., R. Pichs-Madruga, Y. Sokona, E. Farahani, S. Kadner, K. Seyboth, A. Adler, I. Baum, S. Brunner, P. Eickemeier, B. Kriemann, J. Savolainen, S. Schlömer, C. von Stechow, T. Zwickel and J.C. Minx (eds.) (Ed.), Climate Change 2014: Mitigation of Climate Change. Contribution of Working Group III to the Fifth Assessment Report of the Intergovernmental Panel on Climate Change, Cambridge University Press, Cambridge, United Kingdom and New York, NY, USA.

Jacobson, M.Z., Delucchi, M.A., Cameron, M.A., Frew, B.A., 2017. The United States can keep the grid stable at low cost with $100 \%$ clean, renewable energy in all sectors despite inaccurate claims. Proceedings of the National Academy of Sciences 114, E5021-E5023.

Jacobsson, S., Lauber, V., 2006. The politics and policy of energy system transformation-explaining the German diffusion of renewable energy technology. Energy policy 34, 256-276. 
Jansen, E., Overpeck, J., Briffa, K., Duplessy, J., Joos, F., Masson-Delmotte, V., Olago, D., Otto-Bliesner, B., Peltier, W., Rahmstorf, S., 2007. Paleoclimate. Climate Change 2007: The Physical Science Basis. Working Contribution of Working Group I to the Fourth Assessment Report of the Intergovernmental Panel on Climate Change.

Janssen, M.A., Kohler, T.A., Scheffer, M., 2003. Sunk-cost effects and vulnerability to collapse in ancient societies 1 . Current anthropology 44, 722-728.

Jotzo, F., Mazouz, S., 2015. Brown coal exit: a market mechanism for regulated closure of highly emissions intensive power stations. Economic Analysis and Policy 48, 71-81.

Kock, C.J., Min, B.S., 2016. Legal Origins, Corporate Governance, and Environmental Outcomes. J Bus Ethics 138, 507-524.

Kolk, A., Levy, D., 2001. Winds of Change:: Corporate Strategy, Climate change and Oil Multinationals. European Management Journal 19, 501-509.

Krarup, S., Russell, C.S., 2005. Environment, information and consumer behaviour. Edward Elgar Publishing.

Krichene, N., 2002. World crude oil and natural gas: a demand and supply model. Energy economics 24, 557-576.

Lenton, T.M., Pichler, P.P., Weisz, H., 2016. Revolutions in energy input and material cycling in Earth history and human history. Earth Syst. Dynam. 7, 353-370.

Lenton, T.M., van Oijen, M., 2002. Gaia as a complex adaptive system. Philosophical Transactions of the Royal Society of London B: Biological Sciences 357, 683-695.

Lenton, T.M., Watson, A.J., 2000. Redfield revisited: 2. What regulates the oxygen content of the atmosphere? Global Biogeochemical Cycles 14, 249-268.

Levinthal, D.A., March, J.G., 1993. The myopia of learning. Strategic management journal 14, 95-112.

Loewenstein, G., Sunstein, C.R., Golman, R., 2014. Disclosure: Psychology changes everything. Annu. Rev. Econ. 6, $391-419$.

Loorbach, D., Wijsman, K., 2013. Business transition management: exploring a new role for business in sustainability transitions. Journal of Cleaner Production 45, 20-28.

Lovelock, J., Lovelock, J.E., 2000. Gaia: A new look at life on earth. Oxford Paperbacks.

Lovelock, J.E., Watson, A.J., 1982. The regulation of carbon dioxide and climate: Gaia or geochemistry. Planetary and Space Science 30, 795-802.

Lüthi, D., Le Floch, M., Bereiter, B., Blunier, T., Barnola, J.-M., Siegenthaler, U., Raynaud, D., Jouzel, J., Fischer, H., Kawamura, K., 2008. High-resolution carbon dioxide concentration record 650,000-800,000 years before present. Nature 453, 379-382.

Lyon, T.P., Maxwell, J.W., 2008. Corporate social responsibility and the environment: A theoretical perspective. Review of environmental economics and policy 2, 240-260.

Lyons, T.W., Reinhard, C.T., Planavsky, N.J., 2014. The rise of oxygen in Earth/'s early ocean and atmosphere. Nature 506, 307-315.

Masson-Delmotte, V., M. Schulz, A. Abe-Ouchi, J. Beer, A. Ganopolski, J.F. González Rouco, E. Jansen, K. Lambeck, J. Luterbacher, T. Naish, T. Osborn, B. Otto-Bliesner, T. Quinn, R. Ramesh, M. Rojas, X. Shao and A. Timmermann, 2013. Information from Paleoclimate Archives, in: Stocker, T.F., D. Qin, G.-K. Plattner, M. Tignor, S.K. Allen, J. Boschung, A. Nauels, Y. Xia, V. Bex and P.M. Midgley (Ed.), Climate Change 2013: The Physical Science Basis. Contribution of Working Group I to the Fifth Assessment Report of the Intergovernmental Panel on Climate Change. Cambridge University Press, Cambridge, United Kingdom and New York, NY, USA, pp. 383-464.

Maula, M., 1999. Multinational companies as learning and evolving systems : a multiple-case study of knowledge-intensive service companies ; an application of autopoiesis theory. Helsinki : Helsinki School of Economics and Business Administration.

McGlade, C., Ekins, P., 2015. The geographical distribution of fossil fuels unused when limiting global warming to 2 [deg] C. Nature 517, 187-190.

McWilliams, G., 2017. California cities sue big oil firms over climate change, Reuters, https://www.reuters.com/article/legal-us-usa-oilclimatesuits/california-cities-sue-big-oil-firms-over-climate-change-idUSKCN1BV2QM.

Meadows, D.H., 1999. Leverage points: Places to intervene in a system. Sustainability Institute Hartland, VT.

Meadows, D.H., Wright, D., 2008. Thinking in systems: A primer. Chelsea Green Publishing.

Meinshausen, M., Vogel, E., Nauels, A., Lorbacher, K., Meinshausen, N., Etheridge, D.M., Fraser, P.J., Montzka, S.A., Rayner, P.J., Trudinger, C.M., Krummel, P.B., Beyerle, U., Canadell, J.G., Daniel, J.S., Enting, I.G., Law, R.M., Lunder, C.R., O'Doherty, S., Prinn, R.G., Reimann, S., Rubino, M., Velders, G.J.M., Vollmer, M.K., Wang, R.H.J., Weiss, R., 2017. Historical greenhouse gas concentrations for climate modelling (CMIP6). Geosci. Model Dev. 10, 2057-2116.

Michaels, J.D., 2014. Running Government like a Business-Then and Now. HeinOnline.

Mickels, A., 2009. Beyond corporate social responsibility: Reconciling the ideals of a for-benefit corporation with director fiduciary duties in the US and Europe. Hastings Int'l \& Comp. L. Rev. 32, 271.

Mintz, B., Schwartz, M., 1981. Interlocking directorates and interest group formation. American Sociological Review, 851-869.

Mintz, B., Schwartz, M., 1983. Financial interest groups and interlocking directorates. Social Science History 7, 183-204.

Murray, J., 2011. Latchkey Corporations: Fiduciary Duties in Wholly Owned, Financially Troubled Subsidiaries. Del. J. Corp. L. $36,577$.

Murray, J., 2012. Choose Your Own Master: Social Enterprise, Certifications and Benefit Corporation Statutes. Choose Your Own Master: Social Enterprise, Certifications and Benefit Corporation Statutes (June 15, 2012) 2.

Muttit, G., 2017. Forecasting Failure, in: Greenpeace (Ed.), Oil Change International. Greenpeace.

OGJ, 2017. IEA: Upstream oil and gas investment continued to tumble in 2016, in: Editors, O. (Ed.), Capital Spending. Oil\&GasJournal, Houston.

Olson, M., 1971. The logic of collective action: Public goods and the theory of groups, second printing with new preface and appendix (Harvard Economic Studies).

Oreskes, N., Conway, E.M., 2011. Merchants of doubt: How a handful of scientists obscured the truth on issues from tobacco smoke to global warming. Bloomsbury Publishing USA.

Osterwalder, A., 2004. The business model ontology - A proposition in a design science approach. The Business Model Ontology - a proposition in a design science approach.

Paul, A., Lang, J.W.B., Baumgartner, R.J., 2017. A multilevel approach for assessing business strategies on climate change. Journal of Cleaner Production 160, 50-70. 
Pegels, A., Lütkenhorst, W., 2014. Is Germany' s energy transition a case of successful green industrial policy? Contrasting wind and solar PV. Energy Policy 74, 522-534.

Perez, C., 2003. Technological revolutions and financial capital. Edward Elgar Publishing.

Peter Erickson, Sivan Kartha, Lazarus, M., Tempest, K., 2015. Assessing carbon lock-in. Environmental Research Letters 10, 084023.

Phills, J.A., Deiglmeier, K., Miller, D.T., 2008. Rediscovering social innovation. Stanford Social Innovation Review 6, 34-43.

Reeves, M., Deimler, M., 2011. Adaptability: The new competitive advantage. Harvard Business Review.

Reeves, M., Levin, S., 2017. The Biology of Corporate Survival: Natural ecosystems hold surprising lessons for business. Harvard Business Review.

Reeves, M., Levin, S., Ueda, D., 2017. Think Biologically: Messy Management for a Complex World, in: Institute, B.H. (Ed.), BCG Henderson Institute. BCG Henderson Institute, www.bcg.com/publications/2017/.

Riahi, K., Dentener, F., Gielen, D., Grubler, A., Jewell, J., Klimont, Z., Krey, V., McCollum, D., Pachauri, S., Rao, S., 2012. Energy pathways for sustainable development.

Risky Business, P., 2016. From Risk to Return: Investing in a Clean Energy Economy, in: John Carey, T.C., Kate Gordon, and Dan Lashof (Ed.), Risky Business P

roject, riskybusiness.org.

Roberts, J.T., Parks, B., 2006. A climate of injustice: Global inequality, north-south politics, and climate policy. MIT press.

Rocco, M.V., Forcada Ferrer, R.J., Colombo, E., 2018. Understanding the energy metabolism of World economies through the joint use of Production- and Consumption-based energy accountings. Applied Energy 211, 590-603.

Rockström, J., Schellnhuber, H.J., Hoskins, B., Ramanathan, V., Schlosser, P., Brasseur, G.P., Gaffney, O., Nobre, C., Meinshausen, M., Rogelj, J., 2016. The world's biggest gamble. Earth's Future 4, 465-470.

Rogelj, J., Luderer, G., Pietzcker, R.C., Kriegler, E., Schaeffer, M., Krey, V., Riahi, K., 2015. Energy system transformations for limiting endof-century warming to below 1.5 [deg]C. Nature Clim. Change 5, 519-527.

Rogelj, J., Schaeffer, M., Friedlingstein, P., Gillett, N.P., van Vuuren, D.P., Riahi, K., Allen, M., Knutti, R., 2016. Differences between carbon budget estimates unravelled. Nature Climate Change 6, 245-252.

Rosen-Zvi, I., 2011. You Are Too Soft!: What Can Corporate Social Responsibility Do For Climate Change? Minnesota Journal of Law, Science \& Technology 12, 527.

Scheffer, M., Bascompte, J., Brock, W.A., Brovkin, V., Carpenter, S.R., Dakos, V., Held, H., Van Nes, E.H., Rietkerk, M., Sugihara, G., 2009. Early-warning signals for critical transitions. Nature 461, 53-59.

Scheffer, M., Westley, F., Brock, W., 2003. Slow response of societies to new problems: causes and costs. Ecosystems 6, 493-502.

Scheffer, M., Westley, F.R., 2007. The evolutionary basis of rigidity: locks in cells, minds, and society. Ecology and Society $12,36$.

Schellnhuber, H.J., 2009. Tipping elements in the Earth System. Proceedings of the National Academy of Sciences 106, $20561-20563$.

Schumpeter, J.A., 2013. Capitalism, socialism and democracy. Routledge.

Shih, P.M., 2015. Photosynthesis and early Earth. Current Biology 25, R855-R859.

Smil, V., 2008. Energy in nature and society: general energetics of complex systems. MIT press.

Somanathan, E., Sterner, T., Sugiyama, T., Chimanikire, D., Dubash, N.K., Essandoh-Yeddu, J.K., Fifita, S., Goulder, L., Jaffe, A., Labandeira, X., 2014. National and sub-national policies and institutions.

Sorrell, S., 2007. The Rebound Effect: an assessment of the evidence for economy-wide energy savings from improved energy efficiency. UK Energy Research Centre London.

Starr, D., 2016. Just 90 companies are to blame for most climate change, this 'carbon accountant' says, Science. Science, http://www.sciencemag.org/news/2016/08/just-90-companies-are-blame-most-climate-change-carbon-accountant-says.

Stavins R., J.Z., T. Brewer, M. Conte Grand, M. den Elzen, M. Finus, J. Gupta, N. Höhne, M.-K. Lee, A. Michaelowa, M. Paterson,, K. Ramakrishna, G.W., J. Wiener, and H. Winkler,, 2014. International Cooperation: Agreements and Instruments., in: Edenhofer, O., R. Pichs-Madruga, Y. Sokona, E. Farahani, S. Kadner, K. Seyboth, A. Adler, I. Baum, S. Brunner, P. Eickemeier, B. Kriemann, J. Savolainen, S. Schlömer, C. von Stechow, T. Zwickel and J.C. Minx (eds.) (Ed.), Climate Change 2014: Mitigation of Climate Change. Contribution of Working Group III to the Fifth Assessment Report of the Intergovernmental Panel on Climate Change, Cambridge University Press, Cambridge, United Kingdom and New York, NY, USA.

Steffen, W., Crutzen, P.J., McNeill, J.R., 2007. The Anthropocene: are humans now overwhelming the great forces of nature. AMBIO: A Journal of the Human Environment 36, 614-621.

Stern, N.H., 2007. The economics of climate change: the Stern review. cambridge University press.

Stiglitz, J., 2002. The roaring nineties. The Atlantic Monthly 290, 75-89.

Stiglitz, J.E., 2007. Regulating Multinational Corporations: Towards Principles of Cross-Border Legal Framework in a Globalized World Balancing Rights with Responsibilities. Am. U. Int'l L. Rev. 23, 451.

Stout, L.A., 2012. The shareholder value myth: How putting shareholders first harms investors, corporations, and the public. BerrettKoehler Publishers.

Stout, L.A., Blair, M.M., 2017. A team production theory of corporate law, Corporate Governance. Gower, pp. 169-250.

Supran, G., Oreskes, N., 2017. Assessing ExxonMobile's Climate Change Communications (1977-2014). Environmental Research Letters.

Sydow, J., Schreyögg, G., Koch, J., 2009. Organizational path dependence: Opening the black box. Academy of Management Review 34, 689-709.

Tang, L., Koveos, P.E., 2008. A framework to update Hofstede's cultural value indices: economic dynamics and institutional stability. Journal of International Business Studies 39, 1045-1063.

UNFCCC, 2015a. Adoption the Paris ateement, https://unfccc.int/documentation/documents/advanced search/items/6911.php?.priref=600008831.

UNFCCC, 2015b. Six Oil Majors Say: We Will Act Faster with Stronger Carbon Pricing, in: UNFCCC, N. (Ed.), Open Letter to UN and Governments. $\quad$ http://newsroom.unfccc.int/unfccc-newsroom/major-oil-companies-letter-to-un/, http://newsroom.unfccc.int/unfccc-newsroom/major-oil-companies-letter-to-un/.

Vishal Shah, J.B.-P., 2015. Crossing the Chasm: Solar Grid Parity in a Low Oil Price Era, Deutche Bank Markets Research. Deutsche Bank, United States. 
Wainstein, M.E., Bumpus, A.G., 2016. Business Models as Drivers of the Low Carbon Power System Transition: A Multi-Level Perspective. Journal of Cleaner Production.

Walker, B., Holling, C.S., Carpenter, S.R., Kinzig, A., 2004. Resilience, adaptability and transformability in social--ecological systems. Ecology and society 9,5 .

Wallace, P.E., 2008. Climate change, fiduciary duty, and corporate disclosure: Are things heating up in the boardroom. Va. Envtl. LJ 26, 293.

Wallace, P.E., 2009. Climate change, corporate strategy, and corporate law duties. Wake Forest L. Rev. 44, 757.

Whitley, R., 1999. Divergent capitalisms: The social structuring and change of business systems. OUP Oxford.

Williams, A., Kennedy, S., Philipp, F., Whiteman, G., 2017. Systems thinking: A review of sustainability management research. Journal of Cleaner Production 148, 866-881.

Wilson, F., Post, J., 2013. Business models for people, planet (\& profits): exploring the phenomena of social business, a market-based approach to social value creation. Small Business Economics 40, 715-737.

Wilson, J.W., 1975. Market Structure and Interfirm Integration in the Petroleum Industry. Journal of Economic Issues 9, 319-335.

Yeager, K., Dayo, F., Fisher, B., Fouquet, R., Gilau, A., Rogner, H.-H., 2012. Chapter 6 - Energy and Economy, Global Energy Assessment - Toward a Sustainable Future, Cambridge University Press, Cambridge, UK and New York, NY, USA and the International Institute for Applied Systems Analysis, Laxenburg, Austria, pp. 385-422.

Zott, C., Amit, R., Massa, L., 2011. The business model: Recent developments and future research. Journal of Management 37, $1019-1042$. 


\section{Appendix 1: Details and clarifications of the EBS metabolism map -Fig 5.}

The financial capital information represented in Figure 5 is not linked to specific datasets due to the fact that not all information is publicly available (particularly in the case of NOCs and nation states) and has not been compiled by any international agency (Yeager et al., 2012). Carbon and energy information is constructed based on available quantified data (IEA, 2016c). The stocks and flows of carbon and energy in the EBS are depicted as a Sankey diagram of the energy supply chain divided into upstream and downstream, and covering its sources from Earth to the EBS and back in a nested fashion. Although the EBS receives multiple rate-regulating feedback from its environment - eg. from markets, policy and global events - the main feedback mechanism that we evaluate, and attempted to represent graphically in this exercise is the environmental one; responding to the side effects of its combustion metabolism.

The stocks and flows of financial capital are broken into inflows (i.e. sources of capital), outflows (i.e. where the money/capital goes) and assets (i.e. stock resources the EBS owns or controls as a result of its activity). Assets are divided into either cash assets (i.e. stock of money) or all other forms of non-cash assets (e.g. land, equipment, inventory, intellectual property etc.). We represent how all these elements connect by using a concentric circle diagram -termed the EBS 'nucleus'- that is a stylized representation of both an income and cash flow statement - thus as a dynamic process without a specified period of time. This also helps represent shareholder value in the EBS, considered here as a metaphorical boundary that includes all accounted equity (i.e. assets minus liability) and the rent it produces (i.e. dividends and compensations), but also the power of administrating natural energy resources of the Earth system as well as influencing its flows into the societal system. Our analysis frames shareholder value as an integral part of the EBS purpose, and is thus shown with an arrow marking trajectory or drive.

For descriptions of each stock and flow, see Supplementary Material 2.

\section{Supplementary Material:}

(see separate document) 